Article

\title{
Synthetic Approaches for Poly(Phenylene) Block Copolymers via Nickel Coupling Reaction for Fuel Cell Applications
}

\author{
Adam F. Nugraha ${ }^{1,2,+}$, Songmi Kim ${ }^{1,3,+}$, Farid Wijaya ${ }^{1,2}$, Byungchan Bae ${ }^{1,2} \mathbb{D}$ \\ and Dongwon Shin ${ }^{1, *}$ \\ 1 Fuel Cell Laboratory, Korea Institute of Energy Research, Daejeon 34129, Korea; adamfn@kier.re.kr (A.F.N.); \\ songmk307@kier.re.kr (S.K.); faridwijaya@ust.ac.kr (F.W.); bcbae@kier.re.kr (B.B.) \\ 2 Department of Renewable Energy Engineering, University of Science and Technology (UST), \\ Daejeon 34113, Korea \\ 3 Department of Chemical Engineering, Yonsei University, Seoul 03722, Korea \\ * Correspondence: dwshin@kier.re.kr; Tel.: +82-42-860-3019; Fax: +82-42-860-3104 \\ + Both authors contributed equally to this manuscript.
}

Received: 25 June 2020; Accepted: 18 July 2020; Published: 20 July 2020

check for updates

\begin{abstract}
Several methods to synthesize poly(phenylene) block copolymers through the nickel coupling reaction were attempted to reduce the use of expensive nickel catalysts in polymerization. The model reaction for poly(phenylene) having different types of dichlorobenzene derivative monomers illustrated the potential use of cost-effective catalysts, such as $\mathrm{NiBr}_{2}$ and $\mathrm{NiCl}_{2}$, as alternatives to more expensive catalysts (e.g., bis(1,5-cyclooctadiene)nickel(0) (Ni(COD) 2$)$ ). By catalyzing the polymerization of multi-block poly(phenylene) with $\mathrm{NiBr}_{2}$ and $\mathrm{NiCl}_{2}$, random copolymers with similar molecular weights could be prepared. However, these catalysts did not result in a high-molecular-weight polymer, limiting their wide scale application. Further, the amount of $\mathrm{Ni}(\mathrm{COD})_{2}$ could be reduced in this study by approximately $50 \%$ to synthesize poly(phenylene) multi-block copolymers, representing significant cost savings. Gel permeation chromatography and nuclear magnetic resonance results showed that the degree of polymerization and ion exchange capacity of the copolymers were almost the same as those achieved through conventional polymerization using 2.5 times as much $\mathrm{Ni}(\mathrm{COD})_{2}$. The flexible quaternized membrane showed higher chloride ion conductivity than commercial Fumatech membranes with comparable water uptake and promising chemical stability.
\end{abstract}

Keywords: poly(phenylene); multi-block copolymer; nickel coupling reaction; anion-exchange membranes; ion conductivity

\section{Introduction}

Polymer electrolyte membrane fuel cells (PEMFCs) have received considerable attention as efficient and environmentally friendly energy devices [1,2]. PEMFCs are known to be suitable for both stationary and portable applications, including electric vehicles, but they require an expensive platinum catalyst because of the slow oxygen reduction reaction under the acidic operating conditions [3-5]. As an alternative, alkaline membrane fuel cells (AMFCs) seem to be promising because they involve an electrochemical reaction under basic operating conditions, which enables the use of more abundant non-noble-metal catalysts [6-9]. Although AMFCs are economically more advantageous than PEMFCs, the search for a suitable, highly ion-conductive, chemically stable electrolyte membrane has been a challenge for polymer scientists for the last few decades [10]. 
Since the use of Nafion was first reported for PEMFCs, no similar benchmark membranes have been developed for AMFC applications. Although a few membranes are available from Fumatech and Tokuyama, these membranes exhibit low conductivity and stability. Thus, highly conductive and chemically stable anion-exchange membranes (AEMs) have been extensively developed by modifying conventional polymer backbones such as polyethylene, polystyrene, and poly(ether sulfone)s copolymers [11-17]. In addition, numerous synthetic routes for introducing various anion-exchange functional groups have been proposed [9,18-20]. For example, halogenation processes such as chloromethylation and bromination have been widely used to introduce anion-exchange groups into the polymer backbone, followed by a quaternization process [21,22]. However, this process was found to induce side reactions such as crosslinking [20].

Among various polymer backbones, quaternized aromatic polymers are preferred to be used as polymer electrolytes for AMFCs because of their excellent mechanical properties, thermal stability, and favorable hydroxide conductivity. Commonly used polyaromatic electrolytes include quaternized poly(arylene oxide)s, poly(aryl ether ketone)s, and poly(aryl ether sulfone)s, all of which are synthesized via polycondensation reactions [18,23-26]. The anion conductivity of quaternized aromatic polymers has been reported to increase with the increasing water content, as also observed in proton exchange membranes (PEMs), as both membranes undergo a similar water-assisted ion transport mechanism $[27,28]$. Therefore, controlling the polymer morphology, which is a critical factor for ion transport, is essential to maximizing the utilization of water molecules to achieve high ion conductivity. Thus, introducing a multi-block polymer backbone may be a promising approach for enhancing the performance of hydrophilic-hydrophobic phase-separated membranes [9,29-31].

For the long-term stability of AMFCs, the chemical instability of AEMs has also been a formidable concern, particularly because the aryl-ether group ( $\mathrm{C}-\mathrm{O}-\mathrm{C}$ bonds) in the aromatic polymers is chemically unstable under alkaline conditions [21,22,32,33]. The ether linkages close to electron-withdrawing groups such as benzyl trimethylammonium are not resistant to hydroxide ion attack owing to the simultaneous electron deficiency of the aryl group and the low dissociation energy of the ether substituent, thus leading to polymer backbone degradation $[21,22,32,33]$. Therefore, to chemically stabilize AEMs under harsh alkaline conditions, a few research groups have attempted to prepare an aryl-ether-free polyaromatic electrolyte membrane [34,35]. The introduction of a poly(phenylene) backbone can be considered a promising approach for improving AEM stability because of its extremely stable chemical structure.

The nickel-catalyzed carbon-carbon coupling reaction has been used for decades as a method for successfully synthesizing a poly(phenylene) backbone [36-38]. Although the $\mathrm{Ni}(0)$ coupling reaction seems to be the only promising synthetic route for obtaining high-molecular-weight poly(phenylene)s, $\mathrm{Ni}(0)$ catalysts are typically sensitive to oxidation. Bis $\left(1,5\right.$-cyclooctadiene)nickel $(0)\left(\mathrm{Ni}(\mathrm{COD})_{2}\right)$ has been extensively used as the main precatalyst for various applications owing to its stability under an inert atmosphere and low temperatures [10]. However, despite its favorable reactivity, it is limited by its complicated setup, such as the Schlenk technique or the use of a glove box to avoid immediate decomposition upon exposure to air. Hence, the development of alternative $\mathrm{Ni}(0)$-olefin precatalyst, which is stable in air and has reactivity comparable with that of $\mathrm{Ni}(\mathrm{COD})_{2}$, has been a main research goal for many years. Very recently, a new $\mathrm{Ni}(0)$-olefin precatalyst was reported that exhibited similar reactivity with $\mathrm{Ni}(\mathrm{COD})_{2}$ [39]. Although this $\mathrm{Ni}(0)$-olefin complex, which has $p-\mathrm{CF}_{3}$-stilbene derivatives as ligands, offers the advantages of being robust, air-stable, and easy to handle in open flask conditions, its commercialization requires more relevant studies. The cost-effective polymerization of poly(phenylene)s requires either a lower amount of expensive $\mathrm{Ni}(\mathrm{COD})_{2}$ or a process that involves the use of low-cost catalysts such as $\mathrm{NiBr}_{2}$ and $\mathrm{NiCl}_{2}$.

In this study, we investigated the viability of decreasing the amount of expensive $\mathrm{Ni}(\mathrm{COD})_{2}$ catalysts as well as the applicability of low-cost $\mathrm{Ni}$ catalysts by adopting a model reaction for random and block copolymer polymerizations. First, we investigated the feasibility of two other nickel catalysts, $\mathrm{NiBr}_{2}$ and $\mathrm{NiCl}_{2}$, for a model reaction using 2,5-dichloro- $p$-xylene (2,5-DCPX) and 2,4-dichlorotoluene 
(2,4-DCT) as starting materials. Next, we used these catalysts to synthesize a model multi-block polymer from chlorine-telechelic aromatic oligomers and 3,5-dichlorobenzophenone (3,5-DCBP) monomers. Although $\mathrm{NiBr}_{2}$ and $\mathrm{NiCl}_{2}$ were effective in synthesizing the random copolymers, only the $\mathrm{Ni}(\mathrm{COD})_{2}$ catalyst provided a high molecular weight for the model multi-block polymer. Finally, we focused on decreasing the amount of $\mathrm{Ni}(\mathrm{COD})_{2}$ for the synthesis of the amine-containing multi-block poly(phenylene) and successfully decreased the catalyst amount to $50 \%$ of the reported value for the polymerization. The model reaction and polymerization were characterized in detail by gel permeation chromatography (GPC) and nuclear magnetic resonance (NMR). The multi-block poly(phenylene) produced by the optimized synthesis was cast into AEMs by solution casting followed by a quaternization process. Then, the water uptake, ion conductivity, and long-term chemical stability of these membranes were tested for application in AMFCs.

\section{Materials and Methods}

\subsection{Materials}

3,5-Dichlorobenzoyl chloride (3,5-DCBC, $\geq 95 \%)$, lithium aluminum hydride (LAH, $>95 \%)$, 4,4'-dichlorodiphenyl sulfone (>98\%), 2,2-bis(4-hydroxyphenyl)hexafluoropropane ( $>98 \%), m$-xylene (>99.0\%), and 2,2'-bipyridyl (BPY, >99\%) were purchased from Tokyo Chemical Industry (Tokyo, Japan). Dichloromethane (DCM, anhydrous, $\geq 99.8 \%)$, triethylamine ( $\geq 99.5 \%)$, dimethylamine hydrochloride (99\%), 1-methyl-2-pyrrolidinone (NMP, anhydrous, $\geq 99.9 \%$ ), $\mathrm{Ni}(\mathrm{COD})_{2}$, nickel(II) bromide ( $\mathrm{NiBr}_{2}$, $98 \%$ ), nickel(II) chloride ( $\mathrm{NiCl}_{2}, 98 \%$ ), zinc (dust, $<10 \mu \mathrm{m}, \geq 98 \%$ ), 2,5-DCPX (97\%), 2,4-DCT (98\%), benzene (anhydrous, 99.8\%), triphenylphosphine ( $\mathrm{PPh}_{3}$, ReagentPlus $\left.{ }^{\circledR}, 99 \%\right)$, aluminum chloride $\left(\mathrm{AlCl}_{3}\right.$, ReagentPlus $\left.{ }^{\circledR}, 99 \%\right)$, potassium carbonate (anhydrous, free-flowing, Redi-Dri ${ }^{\mathrm{TM}}$, ACS reagent, $\geq 99 \%$ ), iodomethane (containing copper as stabilizer, ReagentPlus ${ }^{\circledR}, 99 \%$ ), lithium bromide ( $\mathrm{LiBr}$, reagent plus $\geq 99 \%$ ), chloroform- $d_{1}\left(\mathrm{CDCl}_{3} ; 99.8\right.$ at $\% \mathrm{D}$, containing $0.1 v / v \%$ tetramethylsilane (TMS)), and dimethyl sulfoxide- $d_{6}$ (DMSO- $d_{6}, 99.9$ at $\%$ D) were purchased from Sigma Aldrich (St. Louis, MO, USA). Toluene (extra pure), $n$-hexane (extra pure), hydrochloric acid (extra pure), sodium bicarbonate, ethyl ether (extra pure), DMSO (extra pure), and dimethylacetamide (DMAc, extra pure) were purchased from Duksan Pure Chemicals (Ansan, Korea). Methanol and ethanol were purchased form Samchun Pure Chemical (Pyeongtaek, Korea). The FAA-3-50 membrane was purchased from Fumatech (St. Ingbert, Germany). Potassium carbonate was dried at $160^{\circ} \mathrm{C}$ overnight before use. Zinc dust was treated with $1 \mathrm{M} \mathrm{HCl}$ in water for $10 \mathrm{~min}$ and then washed with ethyl ether several times and dried under vacuum at $120^{\circ} \mathrm{C}$ overnight. $\mathrm{NiBr}_{2}$ and $\mathrm{NiCl}_{2}$ were dried at $120^{\circ} \mathrm{C}$ under vacuum overnight. $\mathrm{BPY}$ and $\mathrm{PPh}_{3}$ were stored in a glove box under an argon atmosphere before use. All other materials were used as received.

\subsection{Syntheses of Random Poly(Phenylene)s}

As model reactions, random poly(phenylenes) were synthesized using $\mathrm{Ni}(\mathrm{COD})_{2}, \mathrm{NiBr}_{2}$, and $\mathrm{NiCl}_{2}$ to obtain Product 1 (Scheme 1) and Product 2 (Scheme 2). The typical synthetic procedure for the model reaction using $\mathrm{Ni}(\mathrm{COD})_{2}$ is as follows: 2,5-DCPX (0.25 g, $\left.1.4 \mathrm{mmol}\right), 2,4-\mathrm{DCT}(0.23 \mathrm{~g}, 1.4 \mathrm{mmol})$, and BPY $(1.14 \mathrm{~g}, 7.2 \mathrm{mmol})$ were dissolved in $5 \mathrm{~mL}$ of NMP and mixed in a reactor equipped with a mechanical stirrer at $80^{\circ} \mathrm{C}$ under an argon purge. Next, Ni(COD $)_{2}(2.0 \mathrm{~g}, 7.2 \mathrm{mmol})$ was added as a catalyst, and the reaction conditions were maintained for $4 \mathrm{~h}$. After the reaction, the solution was precipitated into $6 \mathrm{M} \mathrm{HCl}$ in methanol and then rinsed with methanol several times. The white precipitate of Product 1 was filtered and dried under vacuum at $80^{\circ} \mathrm{C}$ overnight; the molecular weight was estimated by GPC.

To use the $\mathrm{NiX}_{2}$ as the catalyst, either $\mathrm{NiBr}_{2}(0.11 \mathrm{~g}, 0.5 \mathrm{mmol})$ or $\mathrm{NiCl}_{2}(0.07 \mathrm{~g}, 0.5 \mathrm{mmol})$, zinc $(1.78 \mathrm{~g}, 27.5 \mathrm{mmol}), \mathrm{PPh}_{3}(0.64 \mathrm{~g}, 3.2 \mathrm{mmol})$, and $5 \mathrm{~mL}$ of NMP were charged into a reactor equipped with a mechanical stirrer under an argon purge. After the solution stabilized at $80^{\circ} \mathrm{C}$, a solution of 2,5-DCPX $(0.56 \mathrm{~g}, 3.2 \mathrm{mmol})$ and 2,4-DCT $(0.5 \mathrm{~g}, 3.2 \mathrm{mmol})$ in $5 \mathrm{~mL}$ of NMP was added by injection, and the reaction 
was maintained for $24 \mathrm{~h}$. After the reaction, the solution was precipitated into $6 \mathrm{M} \mathrm{HCl}$ in methanol and then rinsed with methanol several times. The precipitate was then filtered and dried under vacuum at $80{ }^{\circ} \mathrm{C}$ overnight; the molecular weight was estimated by GPC (Younglin Instruments, Anyang, Korea). Product 2 was synthesized by using (3,5-dichlorophenyl)-(2,4-dimethylphenyl)methanone (3,5-DCDMPM) as the monomer following the same procedure as that for Product 1 with each catalyst.<smiles>Cc1cc(Cl)c(C)cc1Cl</smiles>

2,5-Dichloro-p-xylene<smiles>Cc1ccc(Cl)cc1Cl</smiles>

2,4-Dichlorotoluene
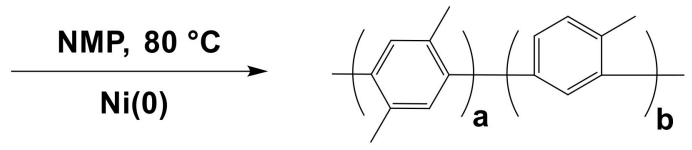

Product 1

Scheme 1. Synthesis of Product 1 as a model reaction.<smiles>Cc1ccc(C(=O)c2cc(Cl)cc(Cl)c2)c(C)c1</smiles>

3,5-DCDMPM
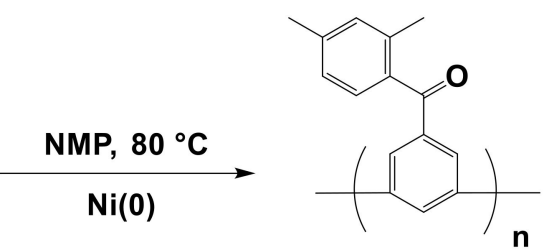

Product 2

Scheme 2. Synthesis of Product 2 as a model reaction.

\subsection{Syntheses of Model Poly(Phenylene) Multi-Block Copolymer with $\mathrm{NiX}_{2}$ and $\mathrm{Ni}(\mathrm{COD})_{2}$}

The syntheses of model poly(phenylene) block copolymers (Product 3 ) were catalyzed by Ni(COD) ${ }_{2}$, $\mathrm{NiBr}_{2}$, and $\mathrm{NiCl}_{2}$, as shown in Scheme 3 . The typical procedure for Product 3 using $\mathrm{Ni}(\mathrm{COD})_{2}$ is almost the same as that for Product 1. 2,5-DCPX and 2,4-DCT were replaced with a chlorine-end-capped aryl ether oligomer (Oligomer AE) and 3,5-DCBP, respectively, to synthesize model multi-block copolymers. The polymerization reaction was maintained for $4 \mathrm{~h}$, and the solution was precipitated into $6 \mathrm{M} \mathrm{HCl}$ in methanol followed by rinsing with methanol several times. The precipitate was filtered and dried under vacuum at $80{ }^{\circ} \mathrm{C}$ overnight to obtain the product, and the molecular weight was estimated by GPC. Polymerization with $\mathrm{NiBr}_{2}$ and $\mathrm{NiCl}_{2}$ followed the same procedure as that for Product 1 . After the polymerization, the purification step was identical to that used for Products 1 and 2.

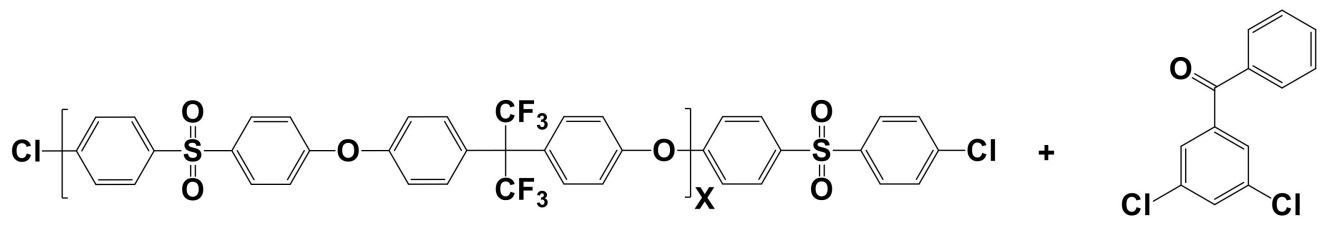

Oligomer AE

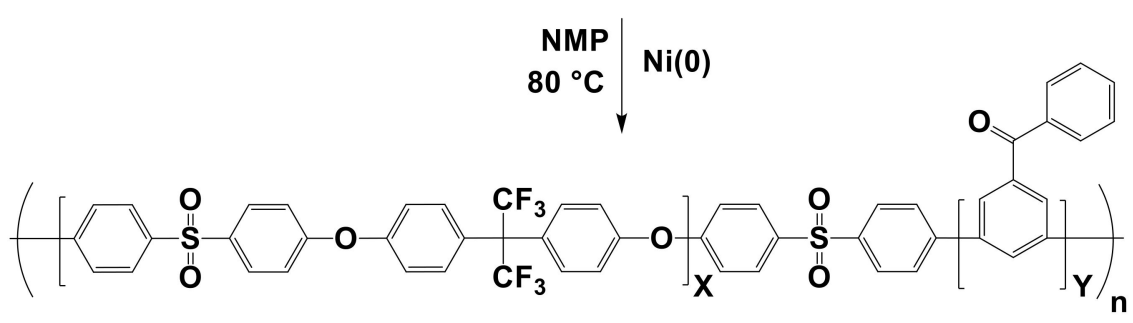

Product 3

Scheme 3. Synthesis of Product 3 using $\mathrm{NiBr}_{2}, \mathrm{NiCl}_{2}$, or $\mathrm{Ni}(\mathrm{COD})_{2}$ as catalysts. 


\subsection{Syntheses of the Amine-Containing Multi-Block Copolymer with $\mathrm{Ni}(\mathrm{COD})_{2}$}

The amine-containing multi-block copolymers (A-Polymer) were synthesized using $\mathrm{Ni}(\mathrm{COD})_{2}$, as shown in Scheme 4. The typical procedure is similar to the polymerization of Product 3 . Oligomer AE was introduced as the hydrophobic component, and 3,5-DCBP was replaced by 3,5-dichloro- $N, N$-dimethylbenzylamine (3,5-DCMBAn) as the precursor hydrophilic component. The feeding ratio of Oligomer AE and 3,5-DCMBAn was maintained at 1:9 to obtain a membrane with $1.80 \mathrm{mEq} \mathrm{g}^{-1}$. During the purification step, the obtained product was washed with a saturated sodium hydrogen bicarbonate aqueous solution, deionized water (DIW), and methanol several times. The polymer was vacuum-dried at $70{ }^{\circ} \mathrm{C}(2.24 \mathrm{~g}, 84.7 \%$ yield $)$.

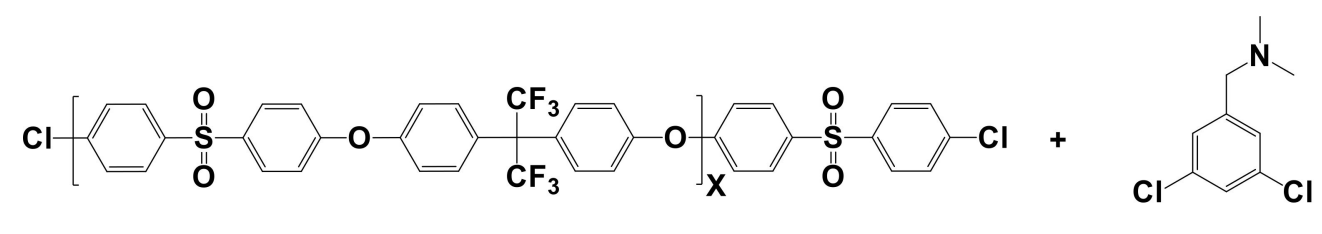

Oligomer AE

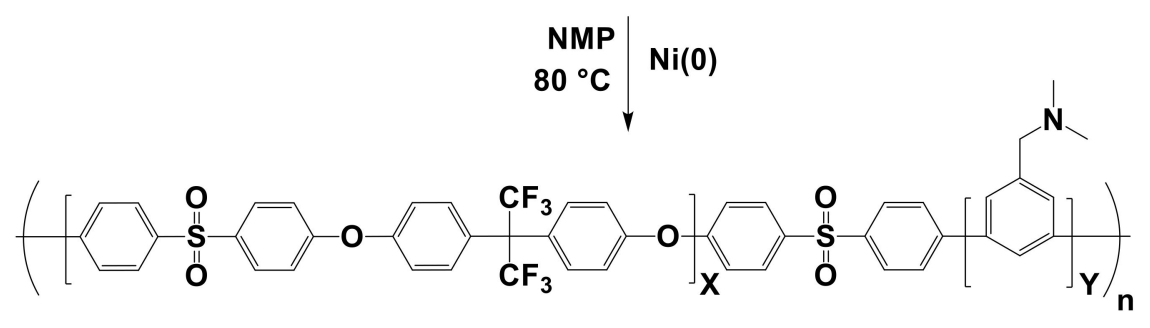

A-Polymer

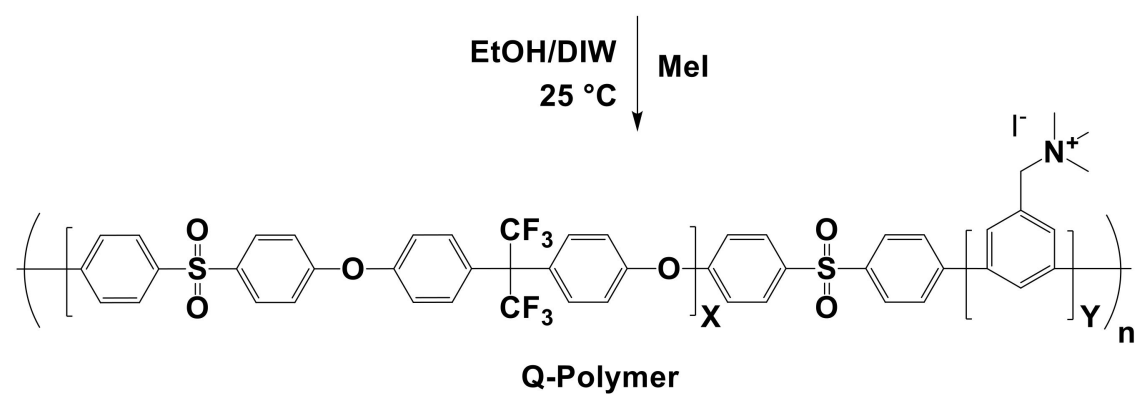

Scheme 4. Polymer synthesis with $\mathrm{Ni}(\mathrm{COD})_{2}$.

\subsection{Membrane Preparation and Quaternization}

The A-Polymer $(0.6 \mathrm{~g})$ was dissolved in NMP $(6 \mathrm{~mL})$, and the solution was cast onto a flat glass plate and dried overnight on a hot plate at $70{ }^{\circ} \mathrm{C}$ in air. The obtained film was further dried in a vacuum oven at $80^{\circ} \mathrm{C}$ for $6 \mathrm{~h}$ to produce a tough, transparent membrane with a thickness of $30 \pm 3 \mu \mathrm{m}$. The membrane was immersed in $5 v / v \%$ iodomethane in an ethanol/DIW (2:1) solution for three days to obtain a quaternized membrane in an iodide ion form. Then, the membrane was separately treated with $1 \mathrm{M} \mathrm{NaOH}$ and $1 \mathrm{M} \mathrm{NaCl}$ aqueous solutions for $24 \mathrm{~h}$ each, followed by washing with DIW several times and drying at room temperature to obtain the membrane in a chloride ion form.

\subsection{Characterization}

The proton ${ }^{1} \mathrm{H}$ NMR spectra were recorded on an AVANCE III (600 MHz) spectrometer (Bruker BioSpin, Billerica, Massachusetts, US), using DMSO- $d_{6}$ or $\mathrm{CDCl}_{3}$ as solvents and $0.1 v / v \%$ TMS as an internal reference. The molecular weights of the polymers were estimated by a GPC instrument equipped with a Yonglin YL9112 isocratic pump and an YL 9120 UV-visible detector (Younglin Instruments, Anyang, Korea). Shodex KF-805L and SB-803HQ columns (Showa Denko K. K., Tokyo, 
Japan) were used to analyze polymers. DMAc containing $0.01 \mathrm{M} \mathrm{LiBr}$ was used as the eluent. Molecular weights were calibrated using polystyrene standard samples.

Membrane ion conductivity $(\sigma)$ was measured using a four-electrode conductivity cell (WonATech, Seoul, Korea) equipped with a Solartron 1260 impedance/gain-phase analyzer and a Solartron 1287 electrochemical interface (Solatron, Farnborough, UK) and was calculated as

$$
\sigma=\frac{D}{L \times T \times R}
$$

where $D$ is the distance between the electrodes, $L$ is the membrane width, $T$ is the membrane thickness, and $R$ is the impedance resistance obtained from the impedance plot in the frequency range of $10^{-1}$ to $10^{5} \mathrm{~Hz}$. Chloride ion conductivity was measured in $25^{\circ} \mathrm{C}$ DIW.

The water uptake was measured by preparing $2 \times 2 \mathrm{~cm}^{2}$ samples, which were dried under vacuum at $100{ }^{\circ} \mathrm{C}$ for $24 \mathrm{~h}$ and immediately weighed on an analytical balance (EM 120-HR, Precisa, Dietikon, Switzerland) at $100{ }^{\circ} \mathrm{C}$. The samples were then soaked in DIW at room temperature for $24 \mathrm{~h}$. The sample weight was measured after removing excess water on the surface. The water uptake was calculated as follows

$$
\text { Water uptake }(\%)=\frac{\left(W_{w}-W_{d}\right)}{W_{d}} \times 100,
$$

where $W_{d}$ and $W_{w}$ are the weights of the dry and fully hydrated membrane, respectively.

The densities of the dried Q-Polymer and Fumatech membranes were assumed to be $\sim 1.5 \mathrm{~g} / \mathrm{cm}^{3}$ based on a previous report [40]. The water volume fraction was calculated from the density and water uptake data by using the following equation

$$
\varphi\left(H_{2} \mathrm{O}\right)=\frac{\rho_{\mathrm{H}_{2} \mathrm{O}}}{\left(\frac{M_{\mathrm{H}_{2} \mathrm{O}}}{\rho_{\mathrm{H}_{2} \mathrm{O}}}+\frac{1}{\rho_{\text {polymer }}} \times \frac{100}{W(\%)}\right)},
$$

where $\rho_{\mathrm{H}_{2} \mathrm{O}}$ is the density of water at $80^{\circ} \mathrm{C}, \mathrm{M}_{\mathrm{H}_{2} \mathrm{O}}$ is the molecular weight, and $\mathrm{W}(\%)$ is the water uptake.

The long-term chemical stability was tested by immersing each membrane equipped with WonATech four-electrode conductivity cells in $1 \mathrm{M}$ aqueous $\mathrm{NaOH}$ at $25^{\circ} \mathrm{C}$ for $700 \mathrm{~h}$ under a nitrogen purge. The $\mathrm{NaOH}$ solution was renewed every three days to prevent contamination with $\mathrm{CO}_{2}$. At the same time, the membrane was washed with DIW several times, and its ion conductivity was measured via impedance spectroscopy in DIW at $25^{\circ} \mathrm{C}$.

\section{Results and Discussion}

\subsection{Synthesis of Random Poly(Phenylene)s}

The model reaction for synthesizing random poly(phenylene)s was performed to investigate the performance of three different Ni catalysts. Product 1 was synthesized from commercially available 2,5-DCPX and 2,4-DCT in the presence of NMP and the nickel catalyst, as shown in Scheme 1. Ni(COD) $\mathrm{NiBr}_{2}$, and $\mathrm{NiCl}_{2}$ were selected as the nickel catalysts for the polymerization, which was monitored by GPC and NMR.

$\mathrm{Ni}(\mathrm{COD})_{2}$ is known to promote the carbon-carbon coupling reaction of aryl halides in the presence of BPY as a ligand in polar solvents [41]. As shown in Scheme 5, the oxidative addition of the aryl (Ar) halide to $\mathrm{Ni}(\mathrm{BPY})(\mathrm{COD})$ gives $\mathrm{NiX}(\mathrm{Ar})(\mathrm{BPY})$ in an early stage of the reaction. The $\mathrm{NiX}(\mathrm{Ar})(\mathrm{BPY})$ complexes then undergo a disproportionation reaction, followed by the formation of carbon-carbon aryl bonds. However, in the coupling reaction using $\mathrm{NiX}_{2}$ as the catalyst, the $\mathrm{NiX}_{2}(\mathrm{BPY})$ complex is known to have significantly lower reactivity toward aryl halides; thus, this catalyst works well only for the most reactive aryl iodides [42]. Therefore, as introduced by Colon and Kelsey (Scheme 6) [43], $\mathrm{PPh}_{3}$ must be incorporated as a ligand to stabilize the catalytically active $\mathrm{Ni}(0)$ complexes, aryl nickel(II), and diaryl nickel intermediates. In this system, zinc metal is used to reduce $\mathrm{Ni}(\mathrm{II})\left(\mathrm{PPh}_{3}\right)_{2} \mathrm{X}_{2}$ in the 
presence of $\mathrm{PPh}_{3}$ to the catalytically active $\mathrm{Ni}(0)\left(\mathrm{PPh}_{3}\right)_{3}$ complex. An excess of $\mathrm{PPh}_{3}$ is required because of the side reaction between $\mathrm{PPh}_{3}$ and zinc halides to obtain zinc complexes. Therefore, a different reagent was tried for each model reaction depending on the type of Ni catalyst, as shown in Table 1.

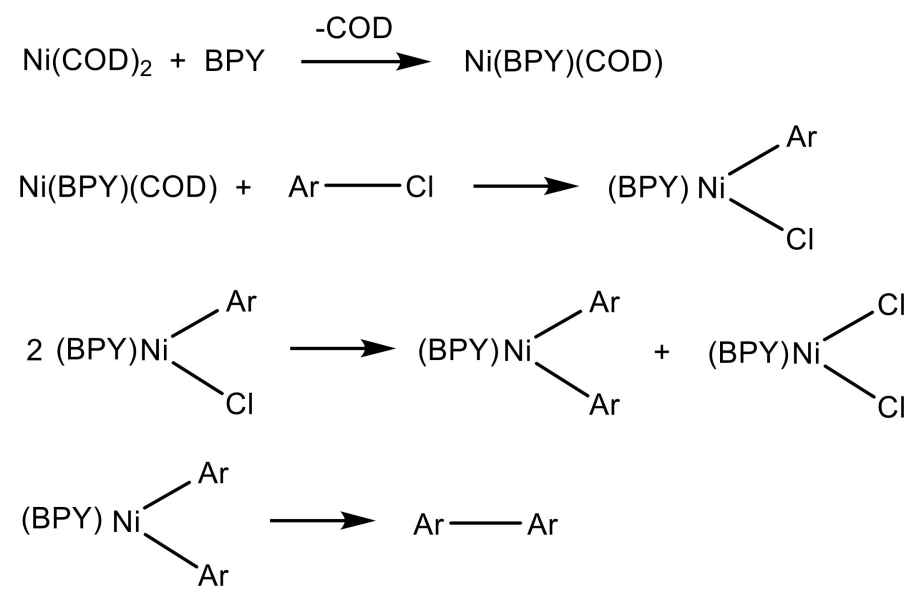

Scheme 5. Mechanism of the nickel coupling reaction with bis(1,5-cyclooctadiene)nickel(0) $\left(\mathrm{Ni}(\mathrm{COD})_{2}\right)[41]$.

$$
\begin{aligned}
& \mathrm{NiX}_{2}+3 \mathrm{~L}+\mathrm{Zn} \longrightarrow \mathrm{Ni}(0) \mathrm{L}_{3}+\mathrm{ZnX}_{2} \\
& \mathrm{Ni}(0) \mathrm{L}_{3}+\mathrm{ArCl} \stackrel{-\mathrm{L}}{\longrightarrow} \mathrm{ArNiCl}_{2} \\
& \mathrm{ArNiCl}_{2}+1 / 2 \mathrm{Zn} \stackrel{+\mathrm{L}}{\longrightarrow} \mathrm{ArNiL}_{3}+1 / 2 \mathrm{ZnCl}_{2} \\
& \mathrm{ArNiL}_{3}+\mathrm{ArCl} \stackrel{-\mathrm{L}}{\longrightarrow} \mathrm{Ar}_{2} \mathrm{NiCl}_{2} \\
& \mathrm{Ar}_{2} \mathrm{NiCl}_{2} \stackrel{+\mathrm{L}}{\longrightarrow} \mathrm{Ar}_{2}+\mathrm{NiClL}_{3} \\
& \mathrm{NiClL}_{3}+1 / 2 \mathrm{Zn} \stackrel{+\mathrm{L}}{\longrightarrow} \mathrm{Ni}(0) \mathrm{L}_{3}
\end{aligned}
$$

Scheme 6. Mechanism of the nickel coupling reaction with $\mathrm{NiX}_{2}$ [43].

Table 1. Product 1 syntheses and molecular weights.

\begin{tabular}{ccccccccc}
\hline Sample & Reactants (mmol) & Catalyst (mmol) & $\mathbf{Z n}(\mathbf{m m o l})$ & $\mathbf{B P Y}(\mathbf{m m o l})$ & $\left.\mathbf{P P h}_{\mathbf{3}} \mathbf{( m m o l}\right)$ & $\mathbf{M}_{\mathbf{n}}{ }^{\mathbf{a}} \mathbf{( k D a )}$ & $\mathbf{M}_{\mathbf{w}}{ }^{\mathbf{a}} \mathbf{( k D a )}$ & $\mathbf{P D I}$ \\
\hline $\mathrm{NiBr}_{2}$ & 6.4 & 0.5 & 27.5 & - & 3.2 & 1.3 & 2.0 & 1.6 \\
$\mathrm{NiCl}_{2}$ & 6.4 & 0.5 & 27.5 & - & 3.2 & 1.5 & 2.3 & 1.6 \\
$\mathrm{Ni}(\mathrm{COD})_{2}$ & 2.9 & 7.2 & - & 7.2 & - & 1.4 & 2.4 & 1.7 \\
\hline
\end{tabular}

${ }^{\text {a }}$ Estimated by GPC analyses (calibrated with polystyrene standards).

After the reaction, the molecular weights of Product 1 were estimated using GPC (Table 1), and the GPC traces are shown in Figure 1. All Ni(0) catalysts showed almost the same degree of polymerization, implying similar catalytic reactivity. The number average molecular weight according to GPC was $1.3 \mathrm{kDa}$ for $\mathrm{NiBr}_{2}, 1.5 \mathrm{kDa}$ for $\mathrm{NiCl}_{2}$, and $1.4 \mathrm{kDa}$ for $\mathrm{Ni}(\mathrm{COD})_{2}$. Their polydispersity index (PDI) values were also similar, ranging from 1.6 to 1.7 , confirming that the catalytic ability of $\mathrm{NiX}_{2}$ is similar to that of $\mathrm{Ni}(\mathrm{COD})_{2}$ in the model reaction.

Figure 2 shows the ${ }^{1} \mathrm{H}$ NMR spectra of 2,5-DCPX, 2,4-DCT, and Product 1 , which was synthesized using $\mathrm{NiBr}_{2}, \mathrm{NiCl}_{2}$, or $\mathrm{Ni}(\mathrm{COD})_{2}$. Typical broad peaks for the phenylene structure (peaks 1, 3, 4, 5) are observed at 6.6-7.6 ppm for Product 1 in all three cases. Broad peaks 2 and 6 of the protons in the methyl group are also observed, indicating the successful reaction for all three catalysts. 


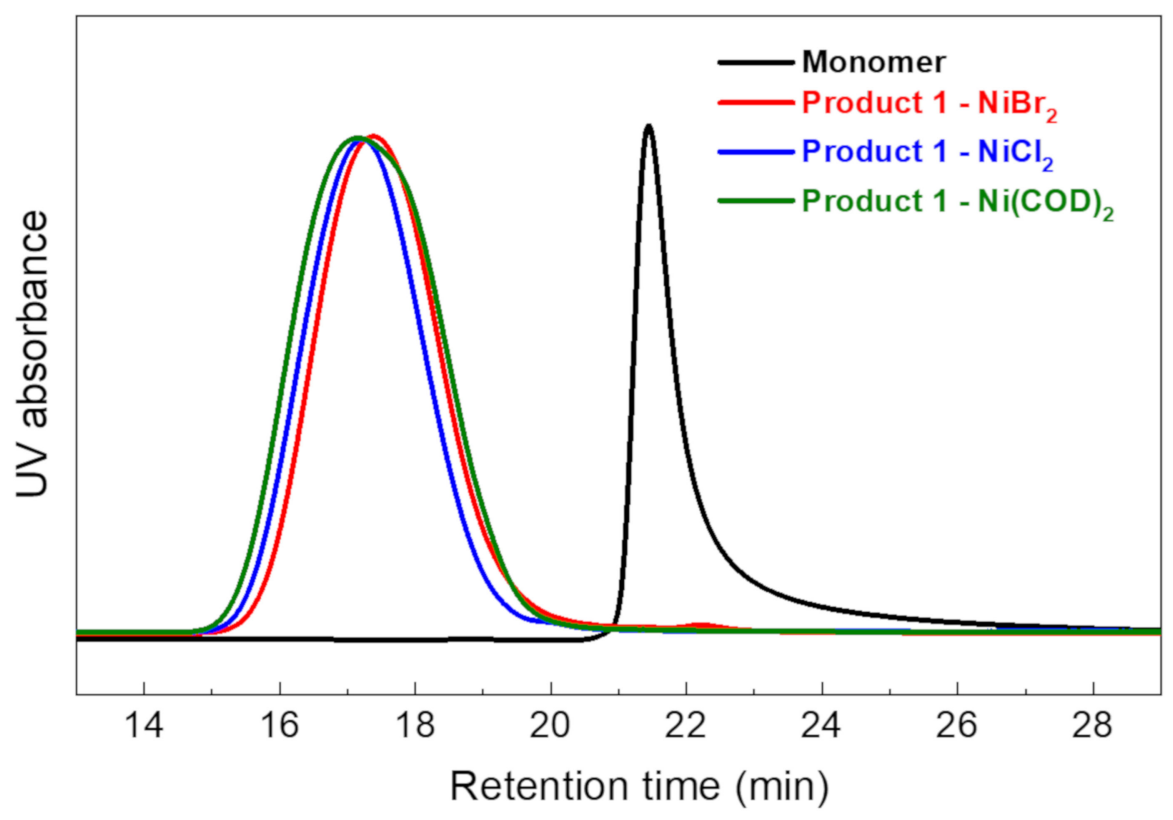

Figure 1. GPC traces of Product 1 with various nickel catalysts.

One of the concerns in regards to the model reaction in Scheme 1 was the low molecular weight of the final polymer owing to the solubility of the growing phenylene polymer. Generally, the $\mathrm{C}-\mathrm{C}$ coupling reaction does not require a stoichiometric balance for polymerization, which is known to be a common principle for polycondensation. In the case of a model step condensation reaction for aromatic polymers, oligomerization by stoichiometric imbalance can enable us to monitor the reactivity of catalysts or monomer alone because the designed low-molecular-weight aromatic oligomers do not have the solubility issue in the reaction solvent. However, the stoichiometric imbalance technique cannot be used for the $\mathrm{C}-\mathrm{C}$ coupling reaction; thus, the degree of polymerization was affected not only by the solubility of the growing rigid phenylene polymer (or oligomer) but also the reactivity of the Ni catalyst. We have found a way to monitor the reactivity of the Ni catalyst during the model reaction because controlling the molecular weight was impossible during the $\mathrm{C}-\mathrm{C}$ coupling reaction. Nevertheless, all Ni catalysts resulted in products with similar molecular weights, which means that similar reactivity was maintained if the growing polymer was soluble during the reaction.

To validate this hypothesis, another model reaction was carried out using different monomer structures bearing benzophenone, which have frequently been used to fabricate p-phenyl electrolyte membranes [44,45]. Product 2 was synthesized from a 3,5-DCDMPM monomer, as shown in Scheme 2. The synthetic procedure of 3,5-DCDMPM and structure confirmation by ${ }^{1} \mathrm{H}$ NMR are provided in Scheme S1 and Figure 3, respectively. The synthesis procedure of Product 2 was similar to that of Product 1 .

Figure 4 shows the GPC traces of Product 2 synthesized using $\mathrm{NiX}_{2}$ and $\mathrm{Ni}(\mathrm{COD})_{2}$. The maximum retention time of the products is shorter than that of the monomer trace, indicating successful polymerization. The estimated molecular weights (Table 2) of the polymers synthesized using $\mathrm{NiBr}_{2}$ $(M n=3.5 \mathrm{kDa}, \mathrm{PDI}=1.80)$ and $\mathrm{NiCl}_{2}(M n=3.7 \mathrm{kDa}, \mathrm{PDI}=1.81)$ are higher than that synthesized with $\mathrm{Ni}(\mathrm{COD})_{2}$ with $\mathrm{Mn}=4.6 \mathrm{kDa}, \mathrm{PDI}=2.20$. This result confirms that $\mathrm{NiX}_{2}$ is a promising alternative to the expensive $\mathrm{Ni}(\mathrm{COD})_{2}$ for the coupling reaction. In addition, Product 2 generally has a higher molecular weight than Product 1 . This result might be explained by the incorporation of the ketone group, which might increase the reactivity of the monomer toward the nickel catalysts [46]. The introduction of a larger side chain may also increase the flexibility of the phenylene polymer, hence increasing the maximum molecular weight. 


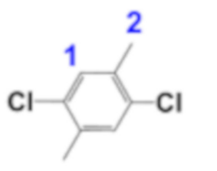

2,5-DCPX

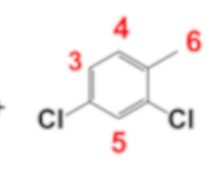

2,4-DCT

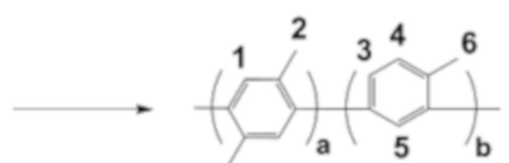

Product 1

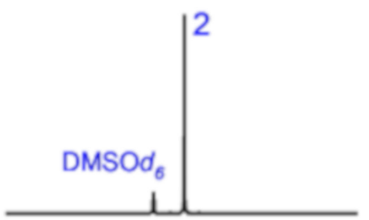

6

$\mathrm{DMSOd}_{6}$
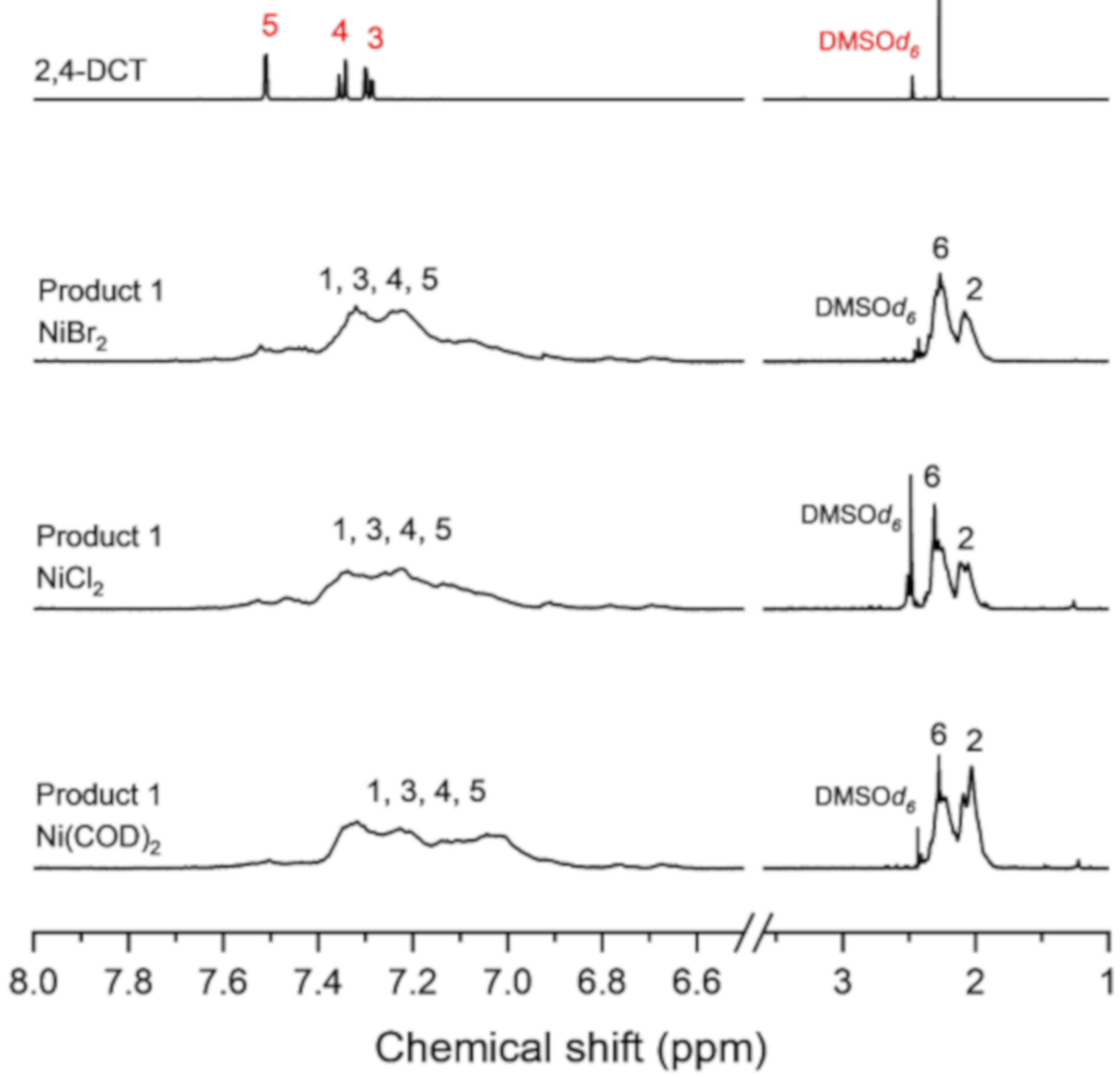

Figure 2. ${ }^{1} \mathrm{H}$ NMR spectra of 2,5-dichloro- $p$-xylene (2,5-DCPX), 2,4-dichlorotoluene (2,4-DCT), and Product 1 synthesized using $\mathrm{NiBr}_{2}, \mathrm{NiCl}_{2}$, or $\mathrm{Ni}(\mathrm{COD})_{2}$.

Figure 3 shows the ${ }^{1} \mathrm{H}$ NMR spectra of the 3,5-DCDMPM monomer and the corresponding Product 2 synthesized using $\mathrm{NiBr}_{2}, \mathrm{NiCl}_{2}$, or $\mathrm{Ni}(\mathrm{COD})_{2}$. Peaks 1 and 2 from 3,5-DCDMPM shift downfield in Product 2 , and the remaining peaks $3-7$ broaden, indicating the successful coupling reaction. Product 2 shows a similar pattern for all three catalysts, confirming the successful catalyzation by $\mathrm{NiBr}_{2}$ and $\mathrm{NiCl}_{2}$ without any side reactions. 


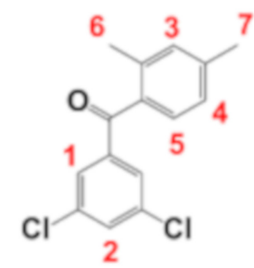

3,5-DCDMPM

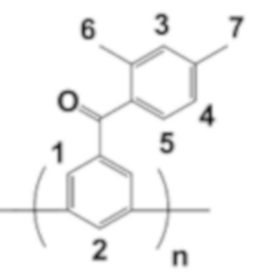

Product 2
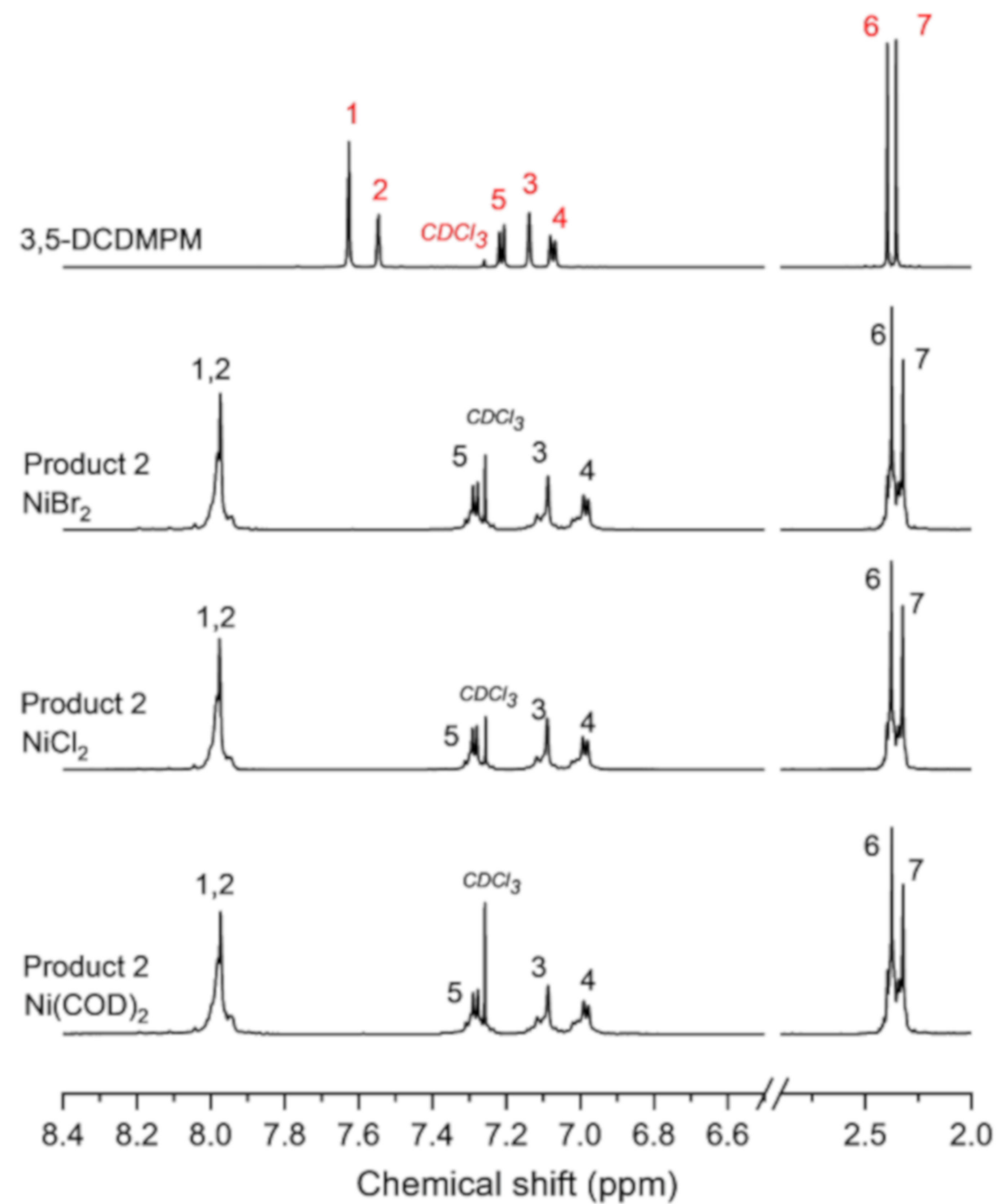

Figure 3. ${ }^{1} \mathrm{H}$ NMR spectra of (3,5-dichlorophenyl)-(2,4-dimethylphenyl)methanone (3,5-DCDMPM) and Product 2 synthesized using $\mathrm{NiBr}_{2}, \mathrm{NiCl}_{2}$, or $\mathrm{Ni}(\mathrm{COD})_{2}$.

Table 2. Product 2 syntheses and molecular weights.

\begin{tabular}{ccccccccc}
\hline Sample & Reactants $(\mathbf{m m o l})$ & Catalyst $(\mathbf{m m o l})$ & $\mathbf{Z n}(\mathbf{m m o l})$ & $\mathbf{B P Y}(\mathbf{m m o l})$ & $\mathbf{P P h}_{\mathbf{3}}(\mathbf{m m o l})$ & $\mathbf{M}_{\mathbf{n}}{ }^{\mathbf{a}} \mathbf{( k D a )}$ & $\mathbf{M}_{\mathbf{w}}{ }^{\mathbf{a}} \mathbf{( k D a )}$ & $\mathbf{P D I}$ \\
\hline $\mathrm{NiBr}_{2}$ & 0.65 & 0.05 & 2.75 & - & 0.32 & 3.5 & 6.2 \\
$\mathrm{NiCl}_{2}$ & 0.65 & 0.05 & 2.75 & - & 0.32 & 3.7 & 6.7 \\
$\mathrm{Ni}(\mathrm{COD})_{2}$ & 0.65 & 1.63 & - & 1.63 & - & 1.8 \\
\hline
\end{tabular}

${ }^{\text {a }}$ Estimated by GPC analyses (calibrated with polystyrene standards). 


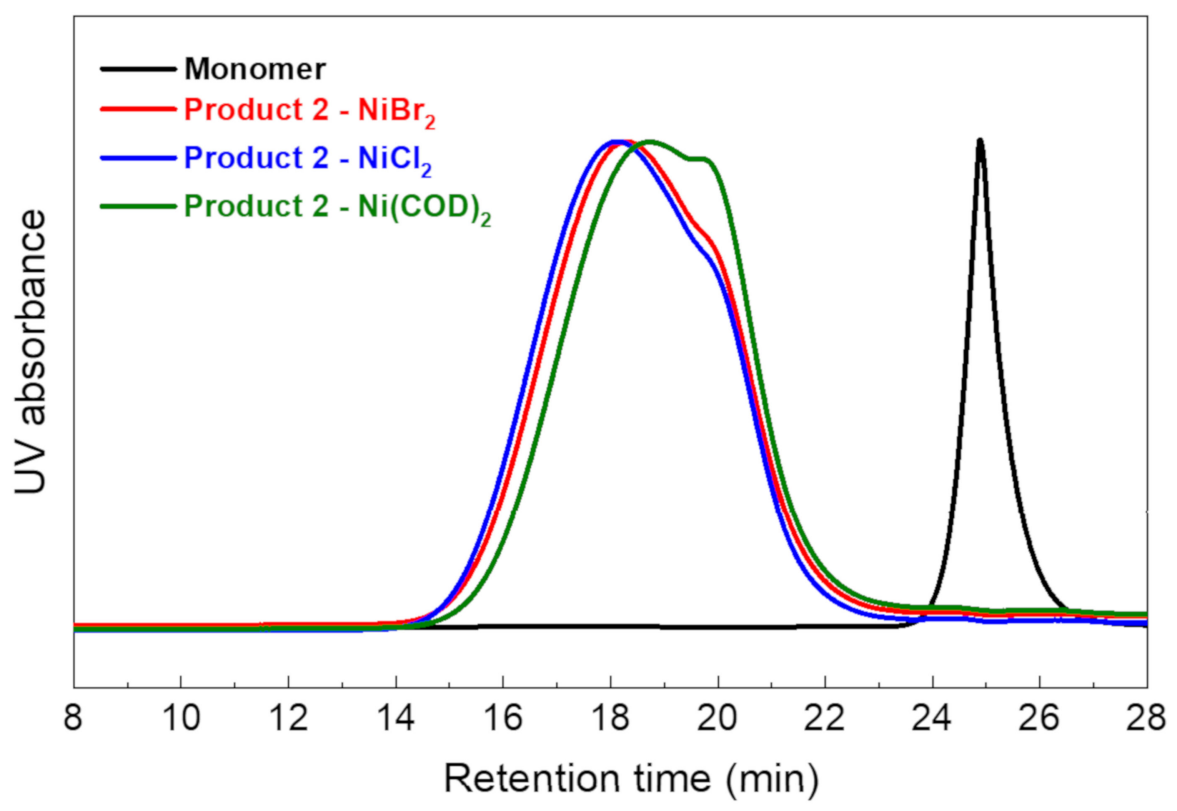

Figure 4. GPC traces of Product 2 with various $\mathrm{Ni}(0)$ catalysts.

\subsection{Synthesis of Poly(Phenylene) from 3,5-DCBP Monomer and Chlorine-Terminated Hydrophobic Oligomer}

Based on the model reactions of Products 1 and 2, we attempted another model reaction to polymerize a multi-block copolymer (Product 3 ) using the three $\mathrm{Ni}(0)$ catalysts. Although $\mathrm{NiBr}_{2}$ and $\mathrm{NiCl}_{2}$ showed similar results to $\mathrm{Ni}(\mathrm{COD})_{2}$ for synthesizing random poly(phenylene) from dichloro-monomers, the polymerization of the multi-block copolymer from a chlorine-terminated oligomer generally required a much higher degree of reactivity. Thus, we designed a relatively simple model multi-block copolymer that does not bear an ionic functional group. Although using a functionalized monomer is preferred to avoid the undesired halogenation process, as discussed in the introduction [20], we intended to minimize the effect of such a functional group on the reactivity of catalysts in the synthesis of Product 3. Functionalized monomers, such as those with amine or ammonium groups, have been reported to hinder the degree of polymerization [43]. The 3,5-DCBP monomer was selected as the hydrophilic block, and Oligomer AE was selected as the hydrophobic block in the model, as shown in Scheme 3. The preparation procedure for 3,5-DCBP is available in the Supporting Information as Scheme S2, and its chemical structure was confirmed by ${ }^{1} \mathrm{H} N M R$, as depicted in Figure 5. Meanwhile, the flexible Oligomer AE was introduced to make the polyphenylene structure of the multi-block backbone less rigid and to obtain a high molecular weight polymer. Oligomer AE was prepared via a nucleophilic aromatic substitution, as described in the Supporting Information (Scheme S3), and the structure was also confirmed by ${ }^{1} \mathrm{H}$ NMR (Figure 5).

The nickel coupling reactions for Product 3 followed a mechanism similar to those for Products 1 and 2. The GPC traces of the starting monomer, Oligomer AE, and the polymer products are shown in Figure 6 . The polymer synthesized using $\mathrm{Ni}(\mathrm{COD})_{2}$ showed a shorter retention time than Oligomer AE, suggesting the successful polymerization process. Figure 5 shows the ${ }^{1} \mathrm{H}$ NMR spectra of Product 3, confirming the chemical structure of the product synthesized using $\mathrm{Ni}(\mathrm{COD})_{2}$. Peaks 1-6 from Oligomer AE remain intact, while peaks 7-8 of the end groups are shifted downfield. Peaks a-e from 3,5-DCBP are significantly shifted and broadened, typical of the poly(phenylene)s structure. The integration ratios of peaks a-e and peaks 1-6 show that the product has X5Y5, similar to the theoretical value. 

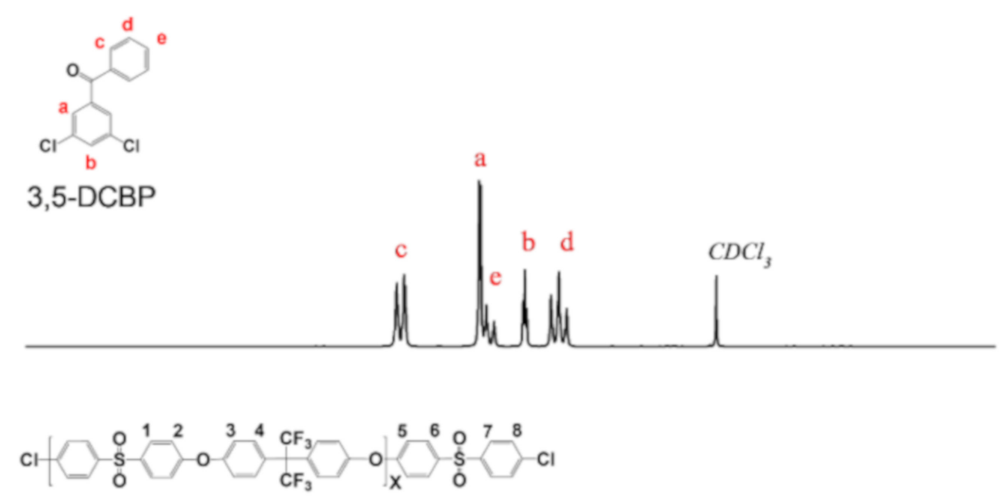

Oligomer AE
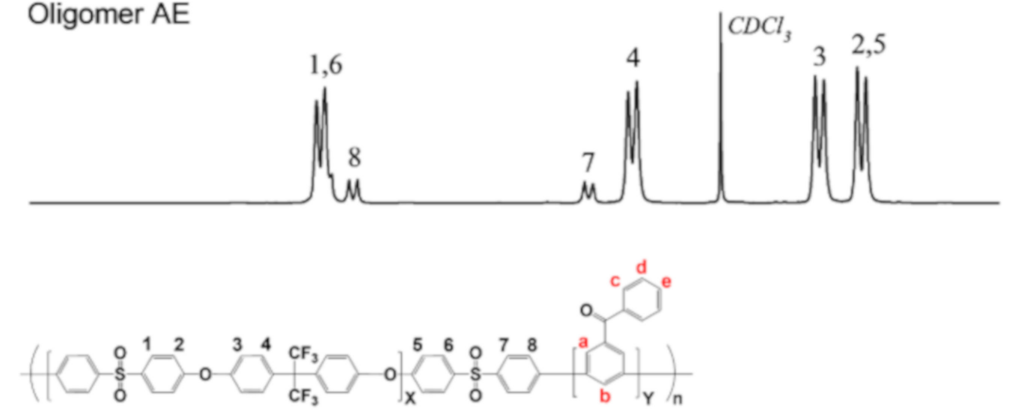

Product 3
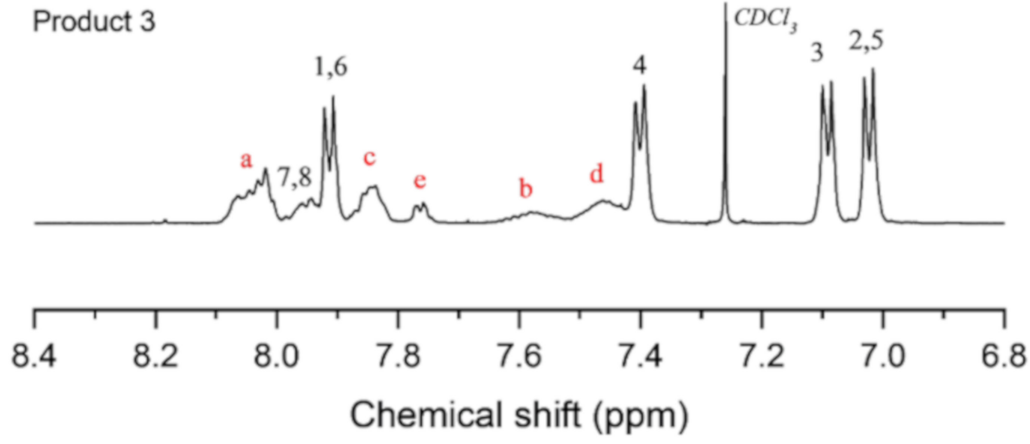

Figure 5. ${ }^{1} \mathrm{H}$ NMR of 3,5-DCBP, Oligomer AE, and Product 3 synthesized using Ni(COD) 2 .

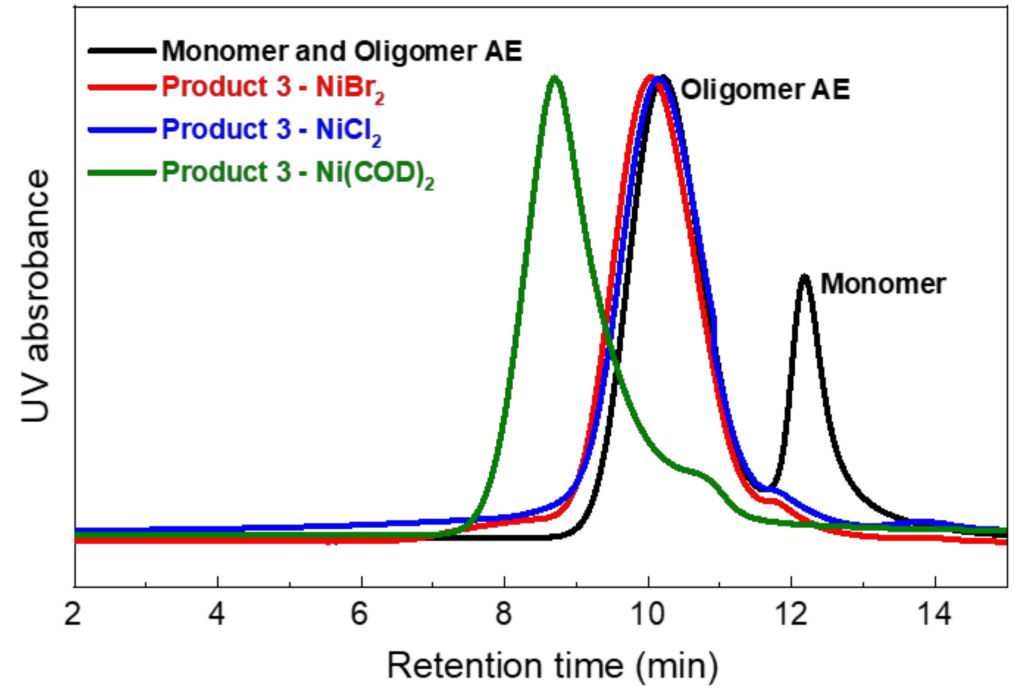

Figure 6. GPC traces of Product 3 synthesized using various nickel catalysts.

In contrast, the GPC traces shift only slightly in the case of the $\mathrm{NiBr}_{2}$ and $\mathrm{NiCl}_{2}$ catalysts, implying unsuccessful reactions. The estimated molecular weights of the polymers are summarized in Table 3. 
Using $\mathrm{Ni}(\mathrm{COD})_{2}$ resulted in a high-molecular-weight copolymer with $M_{w}=131.0 \mathrm{kDa}$ and PDI $=5.6$, which were significantly higher than those of $\mathrm{NiBr}_{2}\left(M_{w}=12.3 \mathrm{kDa}\right.$ and PDI $\left.=2.2\right)$ and $\mathrm{NiCl}_{2}$ $\left(M_{w}=14.2 \mathrm{kDa}\right.$ and PDI $\left.=2.1\right)$. The two $\mathrm{NiX}_{2}$ catalyst systems that were used in the reaction, with phosphorous bidentate ligands, are suspected of having insufficient reactivity with the Oligomer AE. Meanwhile, $\mathrm{Ni}(\mathrm{COD})_{2}$ with the incorporation of BPY as the ligand had higher reactivity with the reactants than the $\mathrm{NiX}_{2}$ systems [41].

Table 3. Product 3 syntheses and molecular weights.

\begin{tabular}{|c|c|c|c|c|c|c|c|c|c|}
\hline Sample & Reactants (mmol) & Catalyst (mmol) & $\mathrm{Zn}$ (mmol) & BPY (mmol) & $\mathrm{PPh}_{3}(\mathrm{mmol})$ & $X Y^{a}$ & $\mathrm{M}_{\mathrm{n}}^{\mathrm{b}}{ }^{(\mathrm{kDa})}$ & $\mathrm{M}_{\mathrm{w}}^{\mathrm{b}}$ (kDa) & PDI \\
\hline $\mathrm{NiCl}_{2}$ & 2.9 & 0.2 & 12.2 & - & 1.4 & X5Y5 & 5.6 & 12.3 & 2.2 \\
\hline $\mathrm{NiBr}_{2}$ & 2.9 & 0.2 & 12.2 & - & 1.4 & X5Y5 & 6.7 & 14.3 & 2.1 \\
\hline $\mathrm{Ni}(\mathrm{COD})_{2}$ & 2.9 & 7.3 & - & 7.3 & - & X5Y5 & 23.4 & 131.0 & 5.6 \\
\hline
\end{tabular}

${ }^{a}$ Calculated from the feeding amount ratio. ${ }^{\mathrm{b}}$ Estimated by GPC analyses (calibrated with polystyrene standards).

Another possible reason for the failure to synthesize Product 3 is the different reactivity of the monomers. Multi-block copolymerization started with a combination of Cl-terminated oligomers and monomers. The oligomers with a $\mathrm{Cl}^{-}$end group would have much lower reactivity than the corresponding monomers owing to their lower mobility, which might hinder the accessibility of the $\mathrm{Ni}(0)$ catalyst, as shown in Scheme 4, resulting in an unsuccessful Ar-Ni coupling reaction. Moreover, sulfone $\left(-\mathrm{SO}_{2}-\right)$ attached to the chlorobenzene end group could lower its electron density, which has been reported to affect the reactivity of the $\mathrm{C}-\mathrm{C}$ coupling reaction [46]. In any case, the catalytic reactivity of $\mathrm{NiX}_{2}$ appears to be insufficient for multi-block copolymerization with oligomers.

\subsection{Synthesis of Amine-Containing Poly(Phenylene) Block Copolymer with Ni(COD) $)_{2}$}

Based on the results of synthesizing Product 3, only $\mathrm{Ni}(\mathrm{COD})_{2}$ was selected for further study, and the research aim became to decrease the use of expensive $\mathrm{Ni}(\mathrm{COD})_{2}$ as much as possible to synthesize AEM multi-block copolymers. The amine-containing poly(phenylene) block copolymer (Polymer) was synthesized from Oligomer AE as the hydrophobic block component and 3,5-DCMBAn as the hydrophilic block component. The preaminated 3,5-DCMBAn was chosen to avoid the halogenation process, as mentioned in Section 1, and it was prepared by the reduction reaction of 3,5-dichloro- $N, N$, dimethybenzamide [47], which was synthesized from 3,5-DCBC via the Schotten-Baumann reaction [48]. The chemical structure of 3,5-DCMBAn was confirmed by ${ }^{1} \mathrm{H}$ NMR, as shown in Figure 7. The multi-block copolymer was synthesized by using different stoichiometric ratios of $\mathrm{Ni}(\mathrm{COD})_{2}$ (Table 4). First, we used a stoichiometric ratio for the model reactions with $2.5 \mathrm{~mol}$ of excess $\mathrm{Ni}(\mathrm{COD})_{2}$ and BPY, similar to that for previously reported reactions $[49,50]$. The synthesized polymer showed a relatively high molecular weight $\left(M_{w}=80.1 \mathrm{kDa}\right)$ and low PDI (3.90) for phenylene polymers. Second, we decreased the amount of $\mathrm{Ni}(\mathrm{COD})_{2}$ and BPY to $1.25 \mathrm{~mol}$ in excess of the monomers and oligomers. This condition gave a low $M_{w}$ of $38.7 \mathrm{kDa}$. As an alternative approach, we increased the amount of BPY to $2.5 \mathrm{~mol}$, while the amount of $\mathrm{Ni}(\mathrm{COD})_{2}$ was unchanged. This approach resulted in a high-molecular-weight polymer with $M_{w}=93.9 \mathrm{kDa}$ and PDI $=3.62$. The molecular weight distribution and GPC traces are presented in Table 4 and Figure 8, respectively.

Table 4. Catalyst ratio and molecular weight distribution of the polymer.

\begin{tabular}{cccc}
\hline Reactants/BPY/Ni(COD) $\mathbf{2}_{\mathbf{2}}$ Ratio & $\mathbf{M}_{\mathbf{n}}{ }^{\mathbf{a}} \mathbf{( k D a )}$ & $\mathbf{M}_{\mathbf{w}}{ }^{\mathbf{a}} \mathbf{( k D a )}$ & PDI \\
\hline $1: 2.5: 2.5$ & 20.5 & 80.1 & 3.9 \\
$1: 1.25: 1.25$ & 2.9 & 38.7 & 13.1 \\
$1: 2.5: 1.25$ & 25.9 & 93.9 & 3.6 \\
\hline
\end{tabular}

${ }^{\text {a }}$ Estimated by GPC analyses (calibrated with polystyrene standards). 

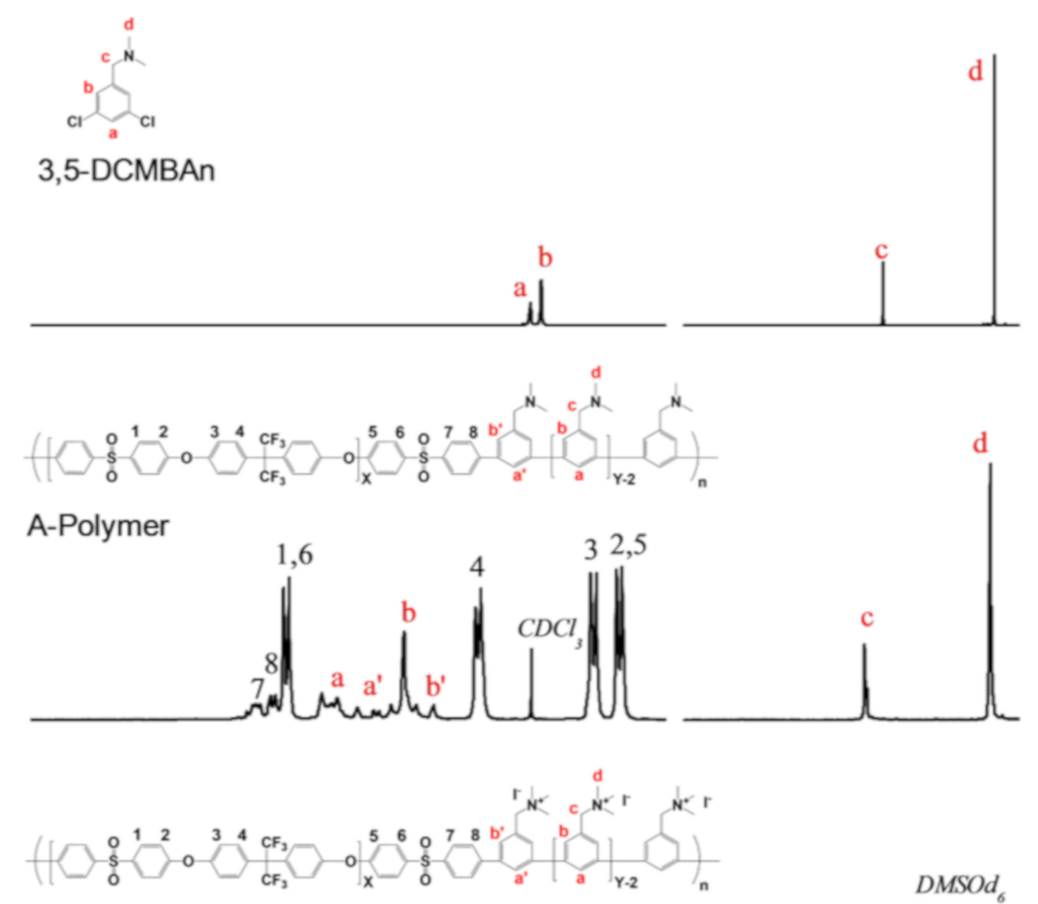

Polymer $2 q$
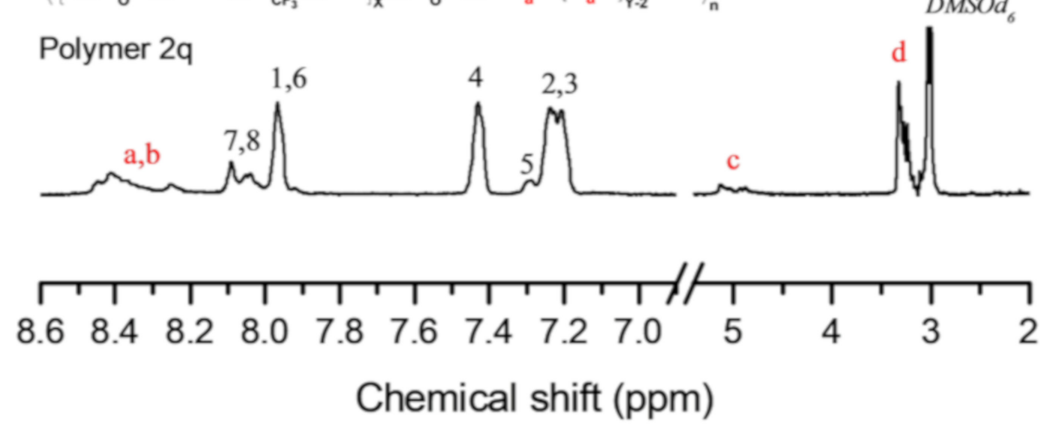

Figure 7. ${ }^{1} \mathrm{H}$ NMR spectra of 3,5-DCMBAn, A-Polymer, and Q-Polymer.

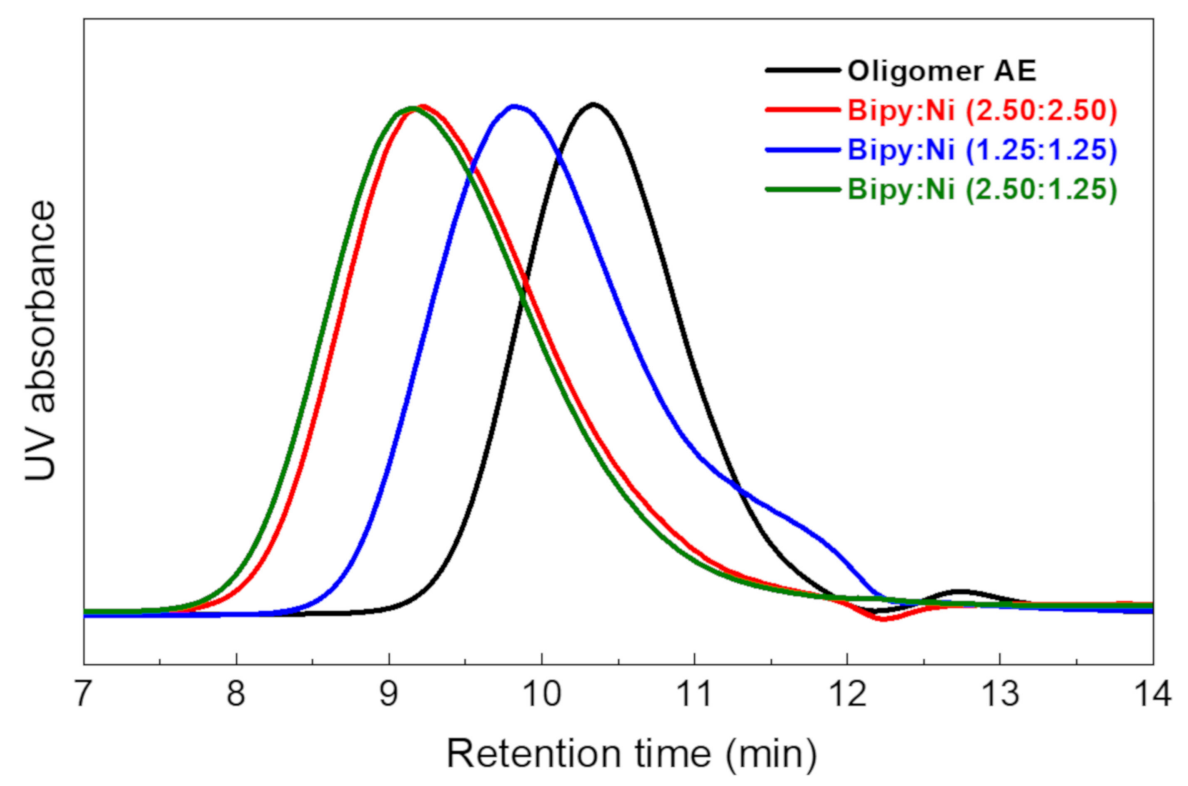

Figure 8. GPC traces of A-Polymer synthesis.

The chemical structure of the polymer was confirmed by ${ }^{1} \mathrm{H}$ NMR, as shown in Figure 7. Peaks 1-8 represent the protons from the hydrophobic block. Peaks 1-6 are present, and peaks 7 and 8 are shifted, 
signifying the coupling reaction of the oligomer end group. Peaks a and $b$ represent the protons from the 3,5-DCMBAn monomers, which shifted after polymerization. The ion exchange capacity (IEC) was estimated from the ratio of the integral area between the hydrophilic and hydrophobic block peaks. The polymer was estimated to have an IEC of $1.77 \mathrm{meq} / \mathrm{g}$, similar to the theoretical value of $1.80 \mathrm{meq} \mathrm{g}^{-1}$ calculated from the feed ratio of Oligomer AE and the monomers.

Although the amount of $\mathrm{Ni}(\mathrm{COD})_{2}$ was decreased by $50 \%$, the $\mathrm{C}-\mathrm{C}$ coupling reaction was still successful. To the best of our knowledge, this amount is the lowest ever reported for p-phenylene polymers. The role of BPY seems to be very distinct based on the results of polymerization because the excess feed of BPY dramatically increased the degree of polymerization. Although the reason for the high molecular weight remains unclear, we can postulate the role of BPY, as shown in the mechanism in Scheme 6. The excess amount of BPY seems to function as a ligand to help generate a $\mathrm{Ni}(\mathrm{BPY})(\mathrm{COD})$ intermediate during polymerization. Specifically, the successful formation of a $\mathrm{Ni}(\mathrm{BPY})(\mathrm{COD})$ intermediate was favored over $\mathrm{NiX}(\mathrm{Ar})(\mathrm{BPY})$, which can induce a disproportionation reaction and the formation of $\mathrm{Ar}-\mathrm{Ar}$ (Scheme 6).

\subsection{Membrane Preparation, Quaternization, and Characterization}

The amine-containing poly(phenylene) block copolymer was soluble in organic solvents such as chloroform, NMP, and DMAc. A membrane with a thickness of $50 \pm 3 \mu \mathrm{m}$ was obtained by solution casting followed by quaternization to provide anion-exchange groups. The quaternized membrane was soluble in DMSO- $d_{6}$, but it was not soluble in the chloroform, DMAc, or NMP, which implied a successful quaternization process. The ${ }^{1} \mathrm{H}$ NMR in Figure 7 confirms the full conversion of benzylamine to benzyl ammonium by comparing the integration value of protons $\mathrm{c}$ and $\mathrm{d}$. The IEC value $\left(1.77 \mathrm{meq} \mathrm{g}^{-1}\right)$ was also confirmed by calculating the integration ratio between proton peaks of the hydrophilic block (a-d) and those of the hydrophobic block (1-8) and comparing the value to the aminated precursor polymers.

The water uptake, swelling volume ratio, and ion conductivity of the quaternized poly(phenylene) multi-block copolymer (Q-Polymer) membrane were measured at $25{ }^{\circ} \mathrm{C}$ in DIW and compared with those of the commercially available Fumatech membrane (FAA-3-50, 2.0 meq $\mathrm{g}^{-1}$ ). The anion of the quaternized membrane was converted into the chloride form for a better comparison and to avoid carbon dioxide contamination. The membrane in the chloride form was bendable, ductile, transparent, and colorless (Figure 9a), and its membrane performance parameters are summarized in Figure $9 \mathrm{~b}$. The Q-Polymer has a lower water uptake (20.1\%) and volume swelling ratio (17.8\%) than the Fumatech membrane (22.3\% and $18.8 \%$, respectively), which might be due to the lower IEC of the block copolymer. On the other hand, the Q-Polymer has higher chloride conductivity $\left(8.8 \mathrm{mS} \mathrm{cm}^{-1}\right)$ than the Fumatech membrane $\left(6.7 \mathrm{mS} \mathrm{cm}^{-1}\right)$. Further, to evaluate the overall performance of the membranes with similar IEC values, a characteristic factor $(\Phi)$ was calculated as the ratio of the chloride conductivity to the water volume fraction [51]. The Q-Polymer exhibits a higher $\Phi$ value $(0.031)$ than the Fumatech membrane (0.022), suggesting more efficient ion transport, despite its lower water content.

The long-term chemical stability of the Q-Polymer was tested under strong alkaline conditions in a similar manner to our previous research to compare its stability with that of the poly(arylene ether) block copolymer membrane (F-PE-2) in that study [19]. Figure 10 shows their hydroxide ion conductivities normalized to their initial values. The Q-Polymer membrane was significantly more stable, retaining $95 \%$ of its conductivity after $700 \mathrm{~h}$, in contrast with F-PE-2, which retained only $24 \%$. This result suggests that introducing the poly(phenylene) structure into the hydrophilic block could improve the chemical stability of the membrane. The degradation of the main chain was probably suppressed by the higher bond dissociation energy of $\mathrm{C}-\mathrm{C}$ bonds than that of $\mathrm{C}-\mathrm{O}$ bonds in the ether substituent [22]. Thus, multi-block poly(phenylene) was successfully synthesized with a lower amount of $\mathrm{Ni}(\mathrm{COD})_{2}$ to obtain a promising membrane for applications in AEMs. 


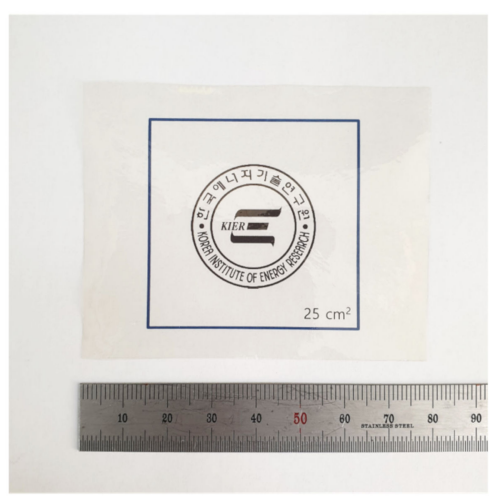

(a)

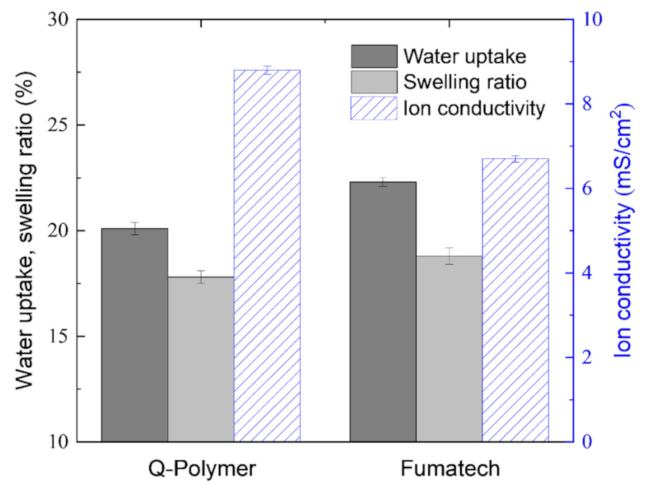

(b)

Figure 9. (a) Photograph of the Q-Polymer membrane $\left(\mathrm{Cl}^{-}\right.$form) and (b) comparison of the water uptake, swelling ratio, and ion conductivity of Q-Polymer and Fumatech (FAA-3-50) membranes measured in deionized water (DIW) at $25^{\circ} \mathrm{C}$.

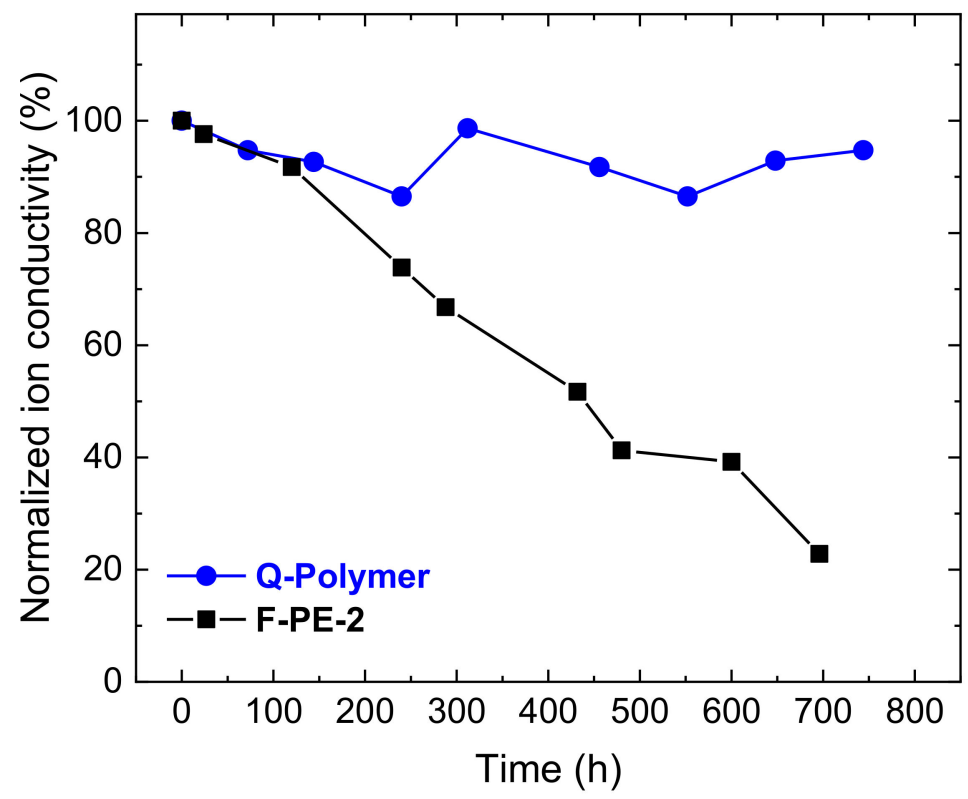

Figure 10. Normalized hydroxide ion conductivity of the Q-polymer membrane during stability testing in a $1 \mathrm{M} \mathrm{NaOH}$ solution at $25^{\circ} \mathrm{C}$ for $700 \mathrm{~h}$, compared with the results of a poly(arylene ether) based membrane, F-PE-2. Adapted with permission from reference [19]. Copyright 2017 Elsevier.

\section{Conclusions}

Several approaches for synthesizing a poly(phenylene)-based block copolymer were investigated with $\mathrm{NiBr}_{2}, \mathrm{NiCl}_{2}$, and $\mathrm{Ni}(\mathrm{COD})_{2}$ catalysts for the carbon-carbon coupling reaction. The low-cost $\mathrm{NiBr}_{2}$ and $\mathrm{NiCl}_{2}$ catalysts showed promising results for the first two model reactions, resulting in a polymer with a molecular weight similar to that achieved with $\mathrm{Ni}(\mathrm{COD})_{2}$. However, $\mathrm{NiBr}_{2}$ and $\mathrm{NiCl}_{2}$ catalysts did not successfully catalyze the model multi-block reaction using a chlorine-terminated oligomer and 3,5-DCBP to synthesize a high-molecular-weight polymer. Thus, another approach was explored to decrease the amount of $\mathrm{Ni}(\mathrm{COD})_{2}$ used to synthesize an amine-containing poly(phenylene) multi-block copolymer. As a result, a high-molecular-weight polymer was obtained by using $1.25 \mathrm{~mol}$ of $\mathrm{Ni}(\mathrm{COD})_{2}$ in excess of the reactant $-50 \%$ less than that commonly used in a similar kind of synthesis. The membrane showed a relatively lower water uptake with higher anion conductivity than the commercial Fumatech membrane in DIW at $25^{\circ} \mathrm{C}$. In addition, introducing the poly(phenylene) backbone in an hydrophilic block could enhance the membrane's chemical stability. Thus, this membrane is a potential alternative to commercial Fumatech membranes, and research on poly(phenylene) multi-block copolymers will be 
continued in the future. To that end, the fuel cell performance of the polymer and its derivatives will be explored in detail.

Supplementary Materials: The following are available online at http://www.mdpi.com/2073-4360/12/7/1614/s1, Synthesis of (3,5-dichlorophenyl)-(2,4-dimethylphenyl)methanone, Synthesis of 3,5-dichlorobenzophenone, Synthesis of chlorine-terminated telechelic hydrophobic oligomers, Scheme S1. Synthesis of 3,5-DCDMPM; Scheme S2. Synthesis of 3,5-DCBP; Scheme S3. Synthesis of Oligomer AE.

Author Contributions: Conceptualization, methodology, investigation, formal analysis, and validation, A.F.N., S.K., and F.W.; writing — original draft preparation and visualization, A.F.N. and S.K.; writing — review and editing, supervision, and project administration, B.B. and D.S.; funding acquisition, B.B. All authors have read and agreed to the published version of the manuscript.

Funding: This research was supported by the Technology Development Program to Solve Climate Change of the National Research Foundation (NRF), funded by the Ministry of Science and ICT (NRF-2018M1A2A2063172).

Conflicts of Interest: The authors declare no conflict of interest.

\section{References}

1. Carrette, L.; Friedrich, K.A.; Stimming, U. Fuel Cells-Fundamentals and Applications. Fuel Cells 2001, 1, 5-39. [CrossRef]

2. Jacobson, M.Z.; Colella, W.G.; Golden, D.M. Cleaning the Air and Improving Health with Hydrogen Fuel-Cell Vehicles. Science 2005, 308, 1901-1905. [CrossRef]

3. Hickner, M.A.; Pivovar, B.S. The Chemical and Structural Nature of Proton Exchange Membrane Fuel Cell Properties. Fuel Cells 2005, 5, 213-229. [CrossRef]

4. Smitha, B.; Sridhar, S.; Khan, A.A. Solid polymer electrolyte membranes for fuel cell applications-A review. J. Membr. Sci. 2005, 259, 10-26. [CrossRef]

5. Wang, B. Recent development of non-platinum catalysts for oxygen reduction reaction. J. Power Sources 2005, 152, 1-15. [CrossRef]

6. Gottesfeld, S.; Dekel, D.R.; Page, M.; Bae, C.; Yan, Y.; Zelenay, P.; Kim, Y.S. Anion exchange membrane fuel cells: Current status and remaining challenges. J. Power Sources 2018, 375, 170-184. [CrossRef]

7. Varcoe, J.R.; Atanassov, P.; Dekel, D.R.; Herring, A.M.; Hickner, M.A.; Kohl, P.A.; Kucernak, A.R.; Mustain, W.E.; Nijmeijer, K.; Scott, K.; et al. Anion-exchange membranes in electrochemical energy systems. Energy Environ. Sci. 2014, 7, 3135-3191. [CrossRef]

8. Jeon, T.-Y.; Kim, S.K.; Pinna, N.; Sharma, A.; Park, J.; Lee, S.Y.; Lee, H.C.; Kang, S.-W.; Lee, H.-K.; Lee, H.H. Selective Dissolution of Surface Nickel Close to Platinum in PtNi Nanocatalyst toward Oxygen Reduction Reaction. Chem. Mater. 2016, 28, 1879-1887. [CrossRef]

9. Weiber, E.A.; Meis, D.; Jannasch, P. Anion conducting multiblock poly(arylene ether sulfone)s containing hydrophilic segments densely functionalized with quaternary ammonium groups. Polym. Chem. 2015, 6, 1986-1996. [CrossRef]

10. You, W.; Noonan, K.J.T.; Coates, G.W. Alkaline-stable anion exchange membranes: A review of synthetic approaches. Prog. Polym. Sci. 2020, 100, 101177. [CrossRef]

11. Sherazi, T.A.; Yong Sohn, J.; Moo Lee, Y.; Guiver, M.D. Polyethylene-based radiation grafted anion-exchange membranes for alkaline fuel cells. J. Membr. Sci. 2013, 441, 148-157. [CrossRef]

12. Mohanty, A.D.; Ryu, C.Y.; Kim, Y.S.; Bae, C. Stable Elastomeric Anion Exchange Membranes Based on Quaternary Ammonium-Tethered Polystyrene-b-poly(ethylene-co-butylene)-b-polystyrene Triblock Copolymers. Macromolecules 2015, 48, 7085-7095. [CrossRef]

13. Dang, H.-S.; Jannasch, P. High-Performing Hydroxide Exchange Membranes with Flexible Tetra-Piperidinium Side Chains Linked by Alkyl Spacers. ACS Appl. Energy Mater. 2018, 1, 2222-2231. [CrossRef]

14. Li, N.; Guiver, M.D.; Binder, W.H. Towards High Conductivity in Anion-Exchange Membranes for Alkaline Fuel Cells. ChemSusChem 2013, 6, 1376-1383. [CrossRef] [PubMed]

15. Kim, Y.; Moh, L.C.H.; Swager, T.M. Anion Exchange Membranes: Enhancement by Addition of Unfunctionalized Triptycene Poly(Ether Sulfone)s. ACS Appl. Mater. Interfaces 2017, 9, 42409-42414. [CrossRef] 
16. Yang, Z.; Guo, R.; Malpass-Evans, R.; Carta, M.; McKeown, N.B.; Guiver, M.D.; Wu, L.; Xu, T. Highly Conductive Anion-Exchange Membranes from Microporous Tröger's Base Polymers. Angew. Chem. Int. Ed. 2016, 55, 11499-11502. [CrossRef]

17. Huang, X.L.; Lin, C.X.; Hu, E.N.; Soyekwo, F.; Zhang, Q.G.; Zhu, A.M.; Liu, Q.L. Imidazolium-functionalized anion exchange membranes using poly(ether sulfone)s as macrocrosslinkers for fuel cells. RSC Adv. 2017, 7, 27342-27353. [CrossRef]

18. Park, J.-S.; Park, S.-H.; Yim, S.-D.; Yoon, Y.-G.; Lee, W.-Y.; Kim, C.-S. Performance of solid alkaline fuel cells employing anion-exchange membranes. J. Power Sources 2008, 178, 620-626. [CrossRef]

19. Kim, E.; Lee, S.; Woo, S.; Park, S.-H.; Yim, S.-D.; Shin, D.; Bae, B. Synthesis and characterization of anion exchange multi-block copolymer membranes with a fluorine moiety as alkaline membrane fuel cells. J. Power Sources 2017, 359, 568-576. [CrossRef]

20. Shin, D.; Nugraha, A.F.; Wijaya, F.; Lee, S.; Kim, E.; Choi, J.; Kim, H.-J.; Bae, B. Synthetic approaches for advanced multi-block anion exchange membranes. RSC Adv. 2019, 9, 21106-21115. [CrossRef]

21. Fujimoto, C.; Kim, D.-S.; Hibbs, M.; Wrobleski, D.; Kim, Y.S. Backbone stability of quaternized polyaromatics for alkaline membrane fuel cells. J. Membr. Sci. 2012, 423-424, 438-449. [CrossRef]

22. Choe, Y.-K.; Fujimoto, C.; Lee, K.-S.; Dalton, L.T.; Ayers, K.; Henson, N.J.; Kim, Y.S. Alkaline Stability of Benzyl Trimethyl Ammonium Functionalized Polyaromatics: A Computational and Experimental Study. Chem. Mater. 2014, 26, 5675-5682. [CrossRef]

23. Fang, J.; Shen, P.K. Quaternized poly(phthalazinon ether sulfone ketone) membrane for anion exchange membrane fuel cells. J. Membr. Sci. 2006, 285, 317-322. [CrossRef]

24. Li, L.; Wang, Y. Quaternized polyethersulfone Cardo anion exchange membranes for direct methanol alkaline fuel cells. J. Membr. Sci. 2005, 262, 1-4. [CrossRef]

25. Willdorf-Cohen, S.; Mondal, A.N.; Dekel, D.R.; Diesendruck, C.E. Chemical stability of poly(phenylene oxide)-based ionomers in an anion exchange-membrane fuel cell environment. J. Mater. Chem. A 2018, 6, 22234-22239. [CrossRef]

26. Yang, Q.; Li, L.; Lin, C.X.; Gao, X.L.; Zhao, C.H.; Zhang, Q.G.; Zhu, A.M.; Liu, Q.L. Hyperbranched poly(arylene ether ketone) anion exchange membranes for fuel cells. J. Membr. Sci. 2018, 560, 77-86. [CrossRef]

27. Hibbs, M.R.; Hickner, M.A.; Alam, T.M.; McIntyre, S.K.; Fujimoto, C.H.; Cornelius, C.J. Transport Properties of Hydroxide and Proton Conducting Membranes. Chem. Mater. 2008, 20, 2566-2573. [CrossRef]

28. Lee, S.; Yuk, J.; Nugraha, A.F.; Shul, Y.-G.; Park, S.-H.; Shin, D.; Bae, B. Partially Fluorinated Multiblock Poly(arylene ether sulfone) Membranes for Fuel Cell Applications. Macromol. Mater. Eng. 2018, 303, 1700650. [CrossRef]

29. Elabd, Y.A. Ion transport in hydroxide conducting block copolymers. Mol. Syst. Des. Eng. 2019, 4, 519-530. [CrossRef]

30. Zhu, M.; Zhang, X.; Wang, Y.; Wu, Y.; Wang, H.; Zhang, M.; Chen, Q.; Shen, Z.; Li, N. Novel anion exchange membranes based on quaternized diblock copolystyrene containing a fluorinated hydrophobic block. J. Membr. Sci. 2018, 554, 264-273. [CrossRef]

31. Yokota, N.; Ono, H.; Miyake, J.; Nishino, E.; Asazawa, K.; Watanabe, M.; Miyatake, K. Anion Conductive Aromatic Block Copolymers Containing Diphenyl Ether or Sulfide Groups for Application to Alkaline Fuel Cells. ACS Appl. Mater. Interfaces 2014, 6, 17044-17052. [CrossRef] [PubMed]

32. Arges, C.G.; Ramani, V. Two-dimensional NMR spectroscopy reveals cation-triggered backbone degradation in polysulfone-based anion exchange membranes. Proc. Natl. Acad. Sci. USA 2013, 110, 2490. [CrossRef] [PubMed]

33. Mohanty, A.D.; Tignor, S.E.; Krause, J.A.; Choe, Y.-K.; Bae, C. Systematic Alkaline Stability Study of Polymer Backbones for Anion Exchange Membrane Applications. Macromolecules 2016, 49, 3361-3372. [CrossRef]

34. Hibbs, M.R.; Fujimoto, C.H.; Cornelius, C.J. Synthesis and Characterization of Poly(phenylene)-Based Anion Exchange Membranes for Alkaline Fuel Cells. Macromolecules 2009, 42, 8316-8321. [CrossRef]

35. Olsson, J.S.; Pham, T.H.; Jannasch, P. Poly(arylene piperidinium) Hydroxide Ion Exchange Membranes: Synthesis, Alkaline Stability, and Conductivity. Adv. Funct. Mater. 2018, 28, 1702758. [CrossRef]

36. Yamamoto, T.; Hayashi, Y.; Yamamoto, A. A Novel Type of Polycondensation Utilizing Transition Metal-Catalyzed C-C Coupling. I. Preparation of Thermostable Polyphenylene Type Polymers. Bull. Chem. Soc. Jpn. 1978, 51, 2091-2097. [CrossRef] 
37. Rehahn, M.; Schlüter, A.-D.; Wegner, G.; Feast, W.J. Soluble poly(para-phenylene)s. 1. Extension of the Yamamoto synthesis to dibromobenzenes substituted with flexible side chains. Polymer 1989, 30, 1054-1059. [CrossRef]

38. Kallitsis, J.K.; Naarmann, H. Synthesis of some disubstituted poly(p-terphenylenes). Synth. Met. 1991, 44, 247-257. [CrossRef]

39. Nattmann, L.; Saeb, R.; Nöthling, N.; Cornella, J. An air-stable binary Ni(0)-olefin catalyst. Nat. Catal. 2020, 3, 6-13. [CrossRef]

40. Bae, B.; Miyatake, K.; Watanabe, M. Sulfonated Poly(arylene ether sulfone ketone) Multiblock Copolymers with Highly Sulfonated Block. Synthesis and Properties. Macromolecules 2010, 43, 2684-2691. [CrossRef]

41. Yamamoto, T.; Wakabayashi, S.; Osakada, K. Mechanism of C-C coupling reactions of aromatic halides, promoted by $\mathrm{Ni}(\mathrm{COD})_{2}$ in the presence of 2,2'-bipyridine and $\mathrm{PPh}_{3}$, to give biaryls. J. Organomet. Chem. 1992, 428, 223-237. [CrossRef]

42. Tanaka, H.; Sumida, S.-I.; Kobayashi, N.; Komatsu, N.; Torii, S. Use of aluminium as an electron pool. Reductive coupling of iodobenzenes promoted by electron transfer in an $\mathrm{Ni} / \mathrm{Pb} / \mathrm{A} 1$ multi redox system. Inorg. Chim. Acta 1994, 222, 323-325. [CrossRef]

43. Colon, I.; Kelsey, D.R. Coupling of aryl chlorides by nickel and reducing metals. J. Org. Chem. 1986, 51, 2627-2637. [CrossRef]

44. Bae, J.M.; Honma, I.; Murata, M.; Yamamoto, T.; Rikukawa, M.; Ogata, N. Properties of selected sulfonated polymers as proton-conducting electrolytes for polymer electrolyte fuel cells. Solid State Ionics 2002, 147, 189-194. [CrossRef]

45. Goto, K.; Rozhanskii, I.; Yamakawa, Y.; Otsuki, T.; Naito, Y. Development of Aromatic Polymer Electrolyte Membrane with High Conductivity and Durability for Fuel Cell. Polym. J. 2009, 41, 95-104. [CrossRef]

46. Hagberg, E.C.; Olson, D.A.; Sheares, V.V. Advances in Ni(0)-Catalyzed Coupling for the Synthesis of Polythiophenes and Polyphenylenes. Macromolecules 2004, 37, 4748-4754. [CrossRef]

47. Micovic, V.; Mihailovic, M. The Reduction of Acid Amides with Lithium Aluminum Hydride. J. Org. Chem. 1953, 18, 1190-1200. [CrossRef]

48. White, T.D.; Berglund, K.D.; Groh, J.M.; Johnson, M.D.; Miller, R.D.; Yates, M.H. Development of a Continuous Schotten-Baumann Route to an Acyl Sulfonamide. Org. Process Res. Dev. 2012, 16, 939-957. [CrossRef]

49. Miyake, J.; Taki, R.; Mochizuki, T.; Shimizu, R.; Akiyama, R.; Uchida, M.; Miyatake, K. Design of flexible polyphenylene proton-conducting membrane for next-generation fuel cells. Sci. Adv. 2017, 3, eaao0476. [CrossRef]

50. Kimura, T.; Matsumoto, A.; Inukai, J.; Miyatake, K. Highly Anion Conductive Polymers: How Do Hexafluoroisopropylidene Groups Affect Membrane Properties and Alkaline Fuel Cell Performance? ACS Appl. Energy Mater. 2020, 3, 469-477. [CrossRef]

51. Yuk, J.; Lee, S.; Nugraha, A.F.; Lee, H.; Park, S.-H.; Yim, S.-D.; Bae, B. Synthesis and characterization of multi-block poly(arylene ether sulfone) membranes with highly sulfonated blocks for use in polymer electrolyte membrane fuel cells. J. Membr. Sci. 2016, 518, 50-59. [CrossRef]

(C) 2020 by the authors. Licensee MDPI, Basel, Switzerland. This article is an open access article distributed under the terms and conditions of the Creative Commons Attribution (CC BY) license (http://creativecommons.org/licenses/by/4.0/). 